\title{
Monotheism Concept in Islam and Famous Religions
}

\author{
Omar Hama Rashid Ahmed \\ Department of Religion Fundamentals, College of Humanities, University of Halabcha, Iraq \\ omar.ahmad@uoh.edu.iq
}

\begin{abstract}
:
God invaded monotheism and believing in him alone is not a partner to him, but the human being deviated as the Messenger (peace be upon him) says in the hadith that he narrates from the Lord of Glory as a result of the deviation and the distance from the law of truth, human beings have established statutory and pagan religions to replace the heavenly religion. Knowing the Truth and falsehood to refute falsehoods and allegations of those who condemn falsehood, but the last message that descended on humanity is the religion of Islam, has special features: the oneness of God became clear and the idols were broken. A book that falsehood does not bring from his hands or from behind him a download from Hakim Hamid. Religious beliefs can be defined in general as the constants that a person embraces and lives his life according to its principles, regardless of the type of religion that he owes. Nature in many religions. This humble effort clarifies the perspective of some living religions towards God, including the heavenly religion and the positivism, so that we learn about their ideas and beliefs, and to warn of their contractual deviations, so that we distinguish between the true religions from the sick.
\end{abstract}

\section{Keywords: $\quad$ Monotheism, Islam, Religions, Instinct, Faith.}

Crossref doi https://doi.org/10.51345/.v32i1.186.g197 


\section{مفهوم التوحيد في الإسلام و الأديان المشهورة \\ د. عمر حمه رشيد أحمد \\ قسم أصول الدين، كلية العلوم الإنسانية، جامعة حلبجة، العراق \\ omar.ahmad@uoh.edu.iq}

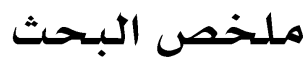

الله فطرنا على التوحيد والإيمان به وحده لاشريك له، ولكن البشر إنحرفوا كما يقول الرسول في الحديث الذي يرويه عن رب العزة (اني خلقت عبادي حنفاء كلهم وأنهم أتتهم الشياطين فاجتالتهم عن دينهم وحرمت عليهم ما أحللت لهم وامرتهم ان يشركوا بي مالم انزل به سلطانا) ونتيجة للإنحر اف والبعد عن شريعة الحق ان قام البشر بإنشاء الأديان الوضعية والوثنية لتحل محل الدين السماوي ولكن الله سبحانه وتعالى أرسل الرسل ليصحح للناس العقيدة وليدعوهم الم عبادة الله وحده لا شريك له والرجوع الى الفطرة الصحيحة، والإسلام دعا المسلم المى دراسة هذه الأديان حتى يتسنى له معرفة الحق والباطل ليرد على إفتراءات وإدعاءات من يدين بالباطل، أما آخر الرسالة الذي نزل على البشرية دين الإسلام، فله ملامح خاصة: اتضحت وحدانية الله وحطمت الأصنام فتح عهد جديد لا يقبل الشرك، وأصبحت الدعوة العامة لكل البشرية، وأصبح محمد رسولاً للعالمين، ودعوة محمد لها كتاب لا يأتيه الباطل من بين يديه ولا من خلفه تنزيل من حكيم حميد. ويمكنُ تعريف المعتقدات

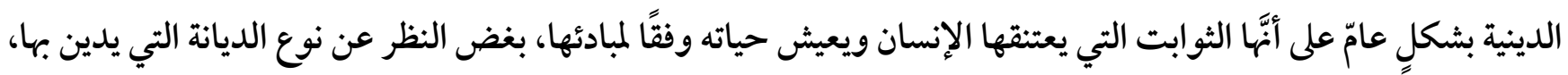
وتتمحور غالب الديانات في العالم حول موضوع وجود إله معين، يؤمن به أتباع هذه الديانة ويخلصون له، وداثئما ما ترتبط المعتقدات الدينية بالطبيعة في كثير من الأديان. وهذا الجهه المتو اضع يوضح منظور بعض الأديان الحية الى الإله، منها الديانة السماوية ومنها الوضعية لنتعرف على افكارهم ومعتقداتهم، ولنحذر من انحر افاتهم العقدية، حتى نفرق بين الدين الصحيح من السقيم. الكلمات المفتاحية: التوحيد، الإسلام، الأديان، الفطرة، الإيهان. Crossref doi https://doi.org/10.51345/.v32i1.186.g197 
المقدمة:

إن عقيدة التوحيد هي الأصل ثم طرأ الشرك على البشرية وكلم) إنحرفت عن طريق التوحيد أرسل الله تعالى الأنبياء والرسل لتذكير بني آدم مرة جديدة بعقيدة التوحيد، ومما يؤيد ذلك قصة الخلق في القرآن الكريم، حيث يذكر الإنسان الأول آدم (عليه السلام) وكان نبياً، وهو أول من سكن الأرض من البشر، وعندما انتكست المجتمعات وتدهورت، أخذت في عبادات المخلوقات الأخرى فعبدوا الشمس لظهورها الدائم و المنافع التي تعود عليهم منها، وما زالت تحتل مكان القداسة عند اليابانيين. كذلك عبدو الإنسان في شخصية الاب أولاً لأنه رمز النعمة والقدرة، ثم تحولت الى عبادة رئيس القبيلة لأنه أكبر قوة وقدرة وعبد قدماء المصريين فرعون، والمى يو منا هذا ما زال ملك اليابان معبود الكثير من أبناء شعبه، إن بعض ديانات الهند منهم من عبد الشمس زاعمين انها ملك من الملائكة ولها نفس وعقل ومنها نور الكواكب وضياء العالم، ومنهم من زعموا ان القمر ملك من الملائكة يستحق التعظيم والعبادة وينسبون اليه تدبير هذا العالم السفلي والأمور الجزئية فيه وبزيادته ونقصانه تعرف الأزمان والساعات، ثم اتخذوا له صنماً يعكفون عليه. أما الإنحدار عن عقيدة التوحيد التي أتى بها الأنبياء والرسل يرجع المى أن سبب نشر لواء الوثنية الجهال الذي أصاب الأجيال

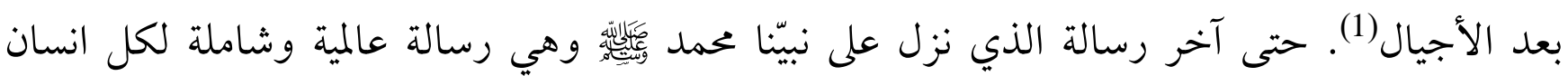
ليخرجهم من الظلمات المى نور الإسلام.

\section{المبحث الأول : مفهوم التوحيد والدين المطلب الأول: مفهوم التوحيد:}

مفهوم التوحيد في اللغة: جاء في لسان العرب: والتوحيد الإِيحان بالله وحده لا شريك له والله الو احِدُ الأَحَدُ ذو

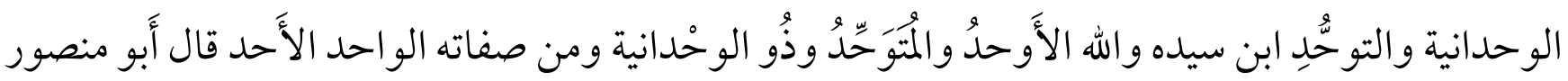
وغيره الفرق بينها أَن الأَحد بني لنفي ما يذكر معه من العدد تقول ما جاءني أَحد والو احد اسم بني لِلِفتِتَح العدد تقول جاءني واحد من الناس ولا تقول جاءني أَحد فالو احد منفرد بالذات في عدم المثل والنظير والأَحد 
منفرد بالمعنى وقيل الو احد هو الذي لا يتجزأُ ولا يشنى ولا يقبل الانقسام ولا نظير له ولا مثل ولا يجمع هذين الو صفين إلا الله عز وجل.

وقال ابن الأَثِير في أَسماء الله تعالى الواحد قال هو الفرد الذي لم يزل وحده ولم يكن معه آخر.

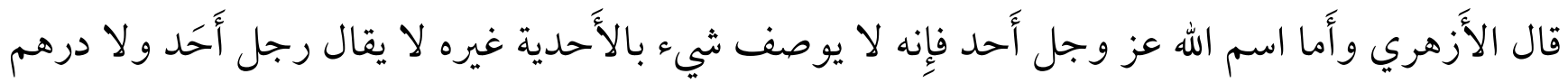

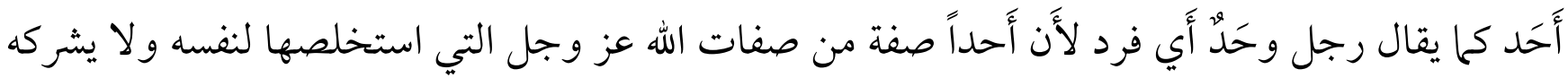
فيها شيء (2) وفي الشرع: (التوحيد) الإيمان بالله تعالى وحده لا شريك له وتجريد الذات الإلهية عن كل ما يتصور في الأفهام ويتخيل في الأوهام والأذهان(3). والتو حيد نفي الكُفه، والمثل عن ذات الله تعالى وصفاته وأفعاله، ونفي الشرك في ربوبيته وعبادته (4). ولكلمة التوحيد أسهاء عديدة في القرآن منها الإخلاص، الإحسان، العدل، الطيبة، الباقية، وكلمة الله هي

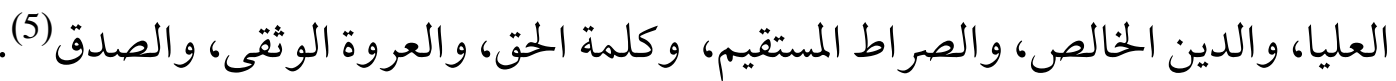

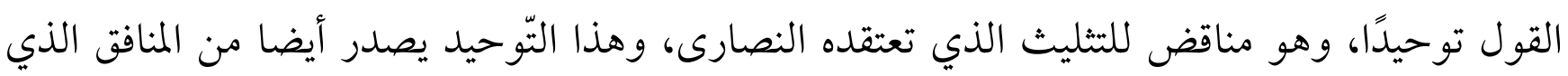

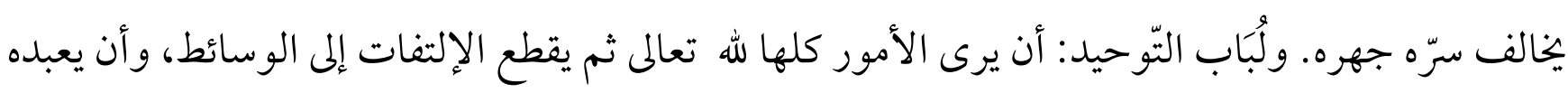

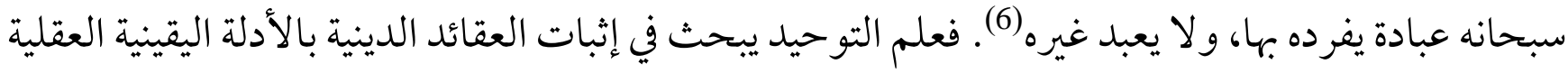
و النقلية، وسمي بعلم التوحيد لأن أهم بحوثه توحيد الله تعالى (7). فكلمة التوحيد يعني (لااله الا الله) معناها: لامعبود بحقّ سوى الله عز وجل، فكلمة التوحيد نفي للالهية عن

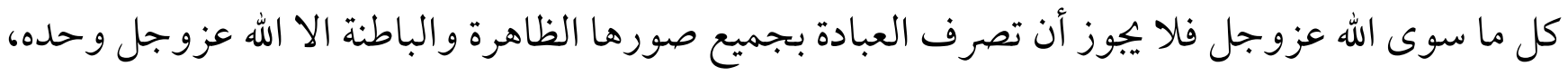
فمن صرف شيئاً من العبادة لغير الله عزوجل فقد وقع في الشرك. وذلك لأن كلمة التوحيد هي أصل الدين وأساسه ورأس أمره، وبقية أركان الدين وفرائضه متفرعة عنها متشعبة منها مكملات لها، إن كلمة التوحيد ليست كلمة ثُنطق باللسان إنما هي منهج حياة بل حياة كله (8). التوحيد : هو افراد بالعبادة كالدعاء والذبح والنذر والصلاة والرجاء والخوف والاستعانة والتوكل وغيرها. 
والتوحيد يشمل العقيدة التي تستقيم بها النفس، والشريعة التي تستقيم بها الحياة، اذ التوحيد الذي يقوم عليه الدين المنزل من عند الله هو توحيد الله في ذاته وتوحيده في صفاته وأفعاله، ومن صفاته التي ينفرد بها سبحانه أنه صاحب الخلق وصاحب الأمر، أما الشرك المقابل التوحيد فهو يقع أما في العبادة (بمعنى التوجه لغير الله بالشعائر التعبدية مع الله أو من دون الله) وإما في الإتباع (بمعنى التحريم والتحليل والمنع والاباحة من دون الله ويغير اذن من الله) و التوحيد هو الذي يصلح الأرض والشرك هو الذي يحدث الفساد الذي ينهي الله عباده عنه (9) - (9) يعد التوحيد المصدر الوحيد لتزويد الإنسان بمنظومة قيم ومنظومة دوافع إنسانية نبيلة. والتوحيد هو أعدل العدل على الاطلاق، كما أن الشرك أظلم الظلم على الاطلاق، مع اختلاف شرائع الأنبياء إلا أن عقيدتهم

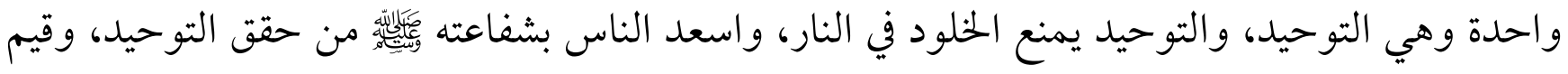
التوحيد هي الأساس الذي تصدر عنه الأخلاق الصحيحة، والايمان شعب ومراتب أعظمها شهادة أن لااله الا الله. والمشرك الذي عدل عن التوحيد لاتحل ذبيحته ولايحل تزويجه ولا غسله ولا الصلاة عليه ولا دفنه في مقابر المسلمين، وان جميع الأقوال والأعال متوقفة في صحتها وفي كمالها وقبولها، والتوحيد هو الضمانة الوحيدة لتحرير الإنسان من قيود نفسه وشهواتها من رياء وكبر ومن أمراض العقل والخرافات. وقد كان الاعراض عن التوحيد سبباً في تسمية القرآن الكريم المعرضين عنه بالمجرمين والظالمين والكاذبين. وإن التوحيد هو الغاية من خلق السموات والأرض والجنة والنار، وهو الغاية من حياة الإنسان ووجدده في الأرض، ما من ريب أن الإنحراف في فهم التوحيد قد وقع وهو أمر يعد أكثر خطراً من غيره فالتوحيد هو أساس الإسلام (10) (2) (2)

\section{المطلب الثاني: مفهوم الدين:}

الدين لغة: وردت كلمة (دين) في معاجم اللغة بمعان نختلفة متقاربة ومتباعدة:

1 - الدين مفرد جمعه الأديان: الدين إسم عام يطلق في اللغة العربية على كل ما يتعبد الله به، يقال دان بكذا

ديانة، تدين به فهو دين ومتدين، ودانه دينا أي أذله واستعبده(11). 
2- يقال دانه، يدينه، أي طاعة وذلّ له، ويقال : دان له أي خضع له، ودان به أي اعتقد به، ويقال : الدين

$$
\text { لله :أي الكم و الخضوع له (12). }
$$

3 - (دين): الدَّيّانُ: من أَسماء الله عز وجل معناه الحكَم القاضي، والدّين: الحسابُ ومنه قوله تعالى:

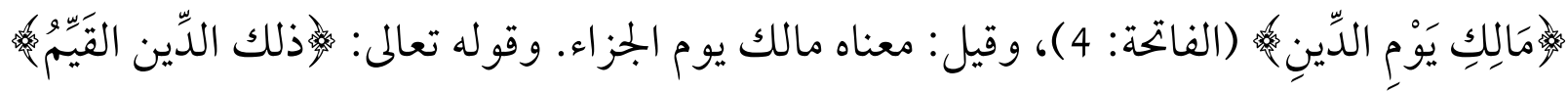

(الروم: 30)، أَي ذلك الحسابُ الصحيح والعدد المستوي، والدِّين: الطاعة. وقد دِنْته ودِنْتُ له

أَطعته: و الدِّين: ما يَتَدَيَّنُ به الرجل . و الدِّينُ: السلطان و الوَرَعُ القهرو المعصية و الطاعة (13).

4 - الدين: كلمة دين ذات صلة وثيقة بالمعاني الآتية: الجَزَاءُ وقد دِنّْهُ بالكسر دَيْناً ويُكْسَرُ والإسلام وقد

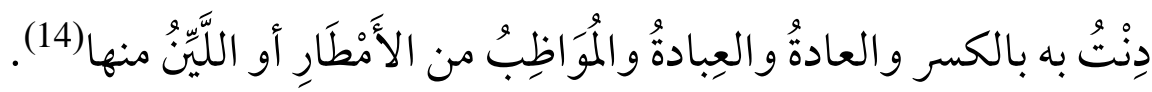

الدين اصطلاحاً: لكثرة الأديان وتعددها واختلافها مما يصعب وضع تعريف للدين شامل لجميع أفراد نوع، فالتعريف الذي قد يستنبط من دين لا ينطبق بالضرورة على الأديان الأخرى، واختلاف فهم الدين وتأويله

لدى كل من الوثنيين وأصحاب الدين السماوي، فليس من السهل تحديد حدود معينة لمعنى الدين (15).

1 - ويعرف أيضاً بأنَّه: (وضع إلهي يرشد إلى الحق في الإعتقادات و إلى الخير في السلوك و المعاملات)(16).

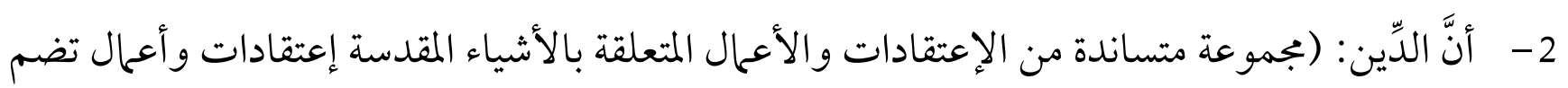

$$
\text { أتباعها في وحدة معنوية تسمى الملة)(17). }
$$

3- يعرف علم)ء الإسلام الدين بأنه: (وضع إلهي سائق لذوي العقول باختيارهم إياه إلى الصلاح في الحال،

$$
\text { و الفلاح في المآل)(18) - (18). }
$$

4- يقول فيلسوف الالملاني عحانوئيل كانت: (الدين هو الشعور بواجباتنا من حيث كونها قائمة على أوامر

$$
\text { الإلهية)(19). }
$$

5- والدين يقال (للطاعة والجزاء واستعير للشريعة، والدين كالملة لكنه يقال اعتبارا بالطاعة والإنقياد

$$
\text { للشريعة) }
$$




\section{المبحث الثاني: مفهوم التوحيد فِ الأديان المشهورة}

نقصد بالأديان المشهورة أي الكبيرة والشائعة وما زال باقية بين الناس منها السماوية كاليهودية والنصرانية والإسلام ومنها الأديان الوضعية كالهندية و الصينية وغيرها من الأديان.

\section{المطلب الأول : الدين الإسـالام:}

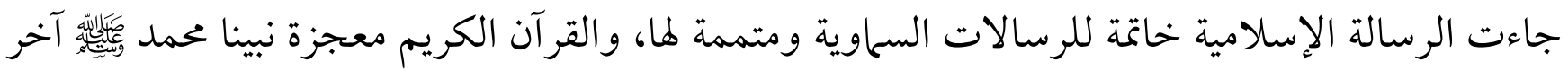
الكتب السماوية نزل بالحق من عند الله الى رسوله الكريم بعلمه تعالى وبشهادة وملائكته المكرمين، وجاء الإسلام للقضاء على الإنحرافات العقائدية والشرك والوثنيات التي غلبت على أمم الأرض، والقرآن الكريم في منهجه للدعوة المى التوحيد الألوهية وإفراد الله سبحانه بالعبادة أقام الأدلة والبراهين على أنه تعالى لا ربَ غيره ولا إله سواه(21). الدين الإسلامي هو الدين الوحيد الذي لم يتخذ فيه الإله شكالً بشرياً أو نحو ذلك من الأشكال، أما المسيحية فإن لفظ (الله) تحيطه تلك الصورة الآدمية لرجل شيخ طاعن في السن قد بانت عليه جميع دلائل الشيخوخة، وكذلك (ياهو) الذي يمثلون به التوحيد اليهودي، إنهم يجعلونه في شكل من المظاهر المتهالكة، والله في البوذية و الكونفيوشيوسية يتمثل في حجارة وتماثيل تمتلىء بها المعابد بل والحدائق أيضاً، أما في دين الإسلام الذي حدث عنه القرآن، فلم يجرؤ مصور أو نحات أن تجري به ريشته، أو ينحته إزميله، ذلك لأن الله لم يخلق الخلق على صورته، وتعالى سبحانه فلم تكن له صورة، ولا حدود محصورة، وهو الو احد الأحد الفرد الصمد، لم يكن له كفواً احد (22).

\section{التوحيد ف이 الإسـالام:}

وحدانية الله في التفكير الإسلامي تشمل الوحدانية في الوجود أي انه إله واحد فليس في الإسلام تعدد آلهة بأية صورة من الصور، وقد لجأ القرآن الكريم للعقل يحكمه في مسالة التوحيد و التعدد، ويثبت بأسلوب منطقي ان

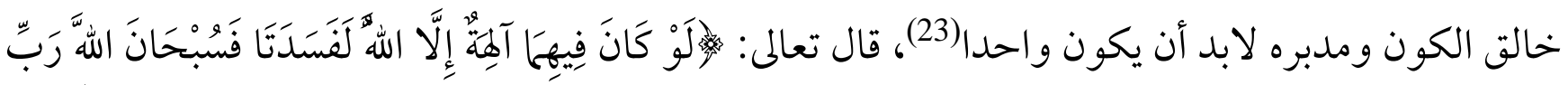

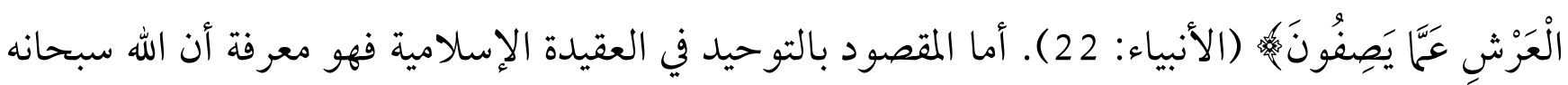
وتعالى واحد في الربوبية ولا شريك له في العبودية، وهو واحد أحد ليس كمثله شيء، قديم لم يزل ولا يزال، 
وهو الأول والآخر، عليم حكيم عادل حي قادر غني سميع بصير، لا يوصف بها توصف به المخلوقات، فليس هو بجسم ولا صورة ولا ندّ له ولا شبه، ولا صاحبة له ولا ولد، ولم يكن له كفوا أحد، لا تدركه الأبصار وهو يدرك الأبصار.

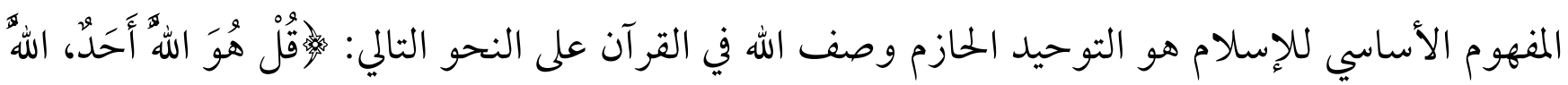

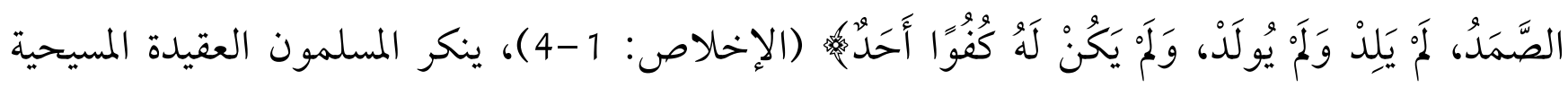
للثالوث(24) وألو هية يوسع، مقارنته بالشرك .في الإسلام، الله هو أبعد من الفهم أو المساواة ولا يشبه أي من إبداعاته بأي شكل من الأشكال. وهكذا، فإن المسلمين ليسوا أيقونيون، ولا يجبذون تصوير الله. فإن الدين

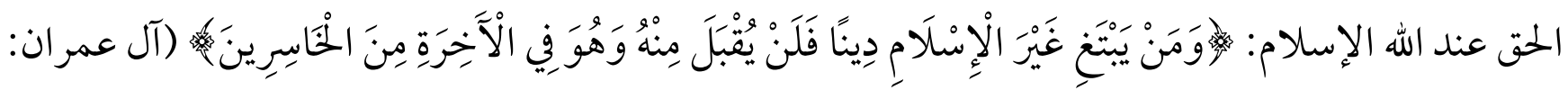

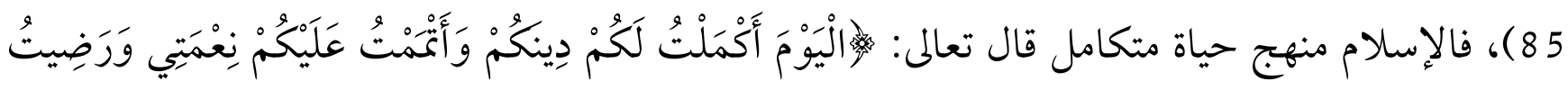

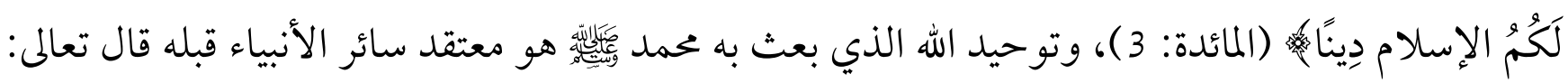

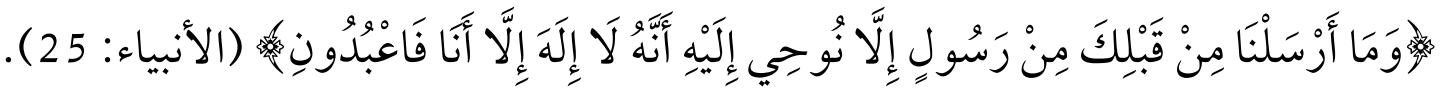
التوحيد هو إفراد الله سبحانه بالعبادة، وهو دين الرسل الذين أرسلهم الله إلى عباده، وهو أول واجب على كل ذكر وأنثى، وهو أعظم ما أمر الله به، ولا خلاف أن التوحيد لابد أن يكون بالقلب واللسان والعمل، فإن اختل شيء من هذا لم يكن الرجل مسلماً، فإن عرف التوحيد ولم يعمل به فهو كافر معاند كفرعون وإبليس و أمثالهما، وإن عمل بالتوحيد ظاهراً، وهو لايفهمه أو لايعتقده بقلبه فهو منافق، وهو شرمن الكافر الخالص. والبحث عن مسائل التوحيد وتعلمها فرض لازم على العالم والجاهل والمحرم و المحل و الذكر والأنثى (25).

\section{التوحيد يِّ الإسـلام ينقسهم الى ثلاثة أقسام(26):}

$$
1
$$

معناه هو العلم والإعتقاد والإعتراف بأن للكون خالقاً واحداً ومالكاً واحداً هو الله عز وجل، وأنه وحده المنفرد في هذا العالم بالخلق وأنواع التدبير والتصرف، من الإيجاد والرزق والأحياء، لا يتصرف في ملكه سواه إلا بأذنه ليس له شريك في الملك، لا راد لأمره، ما شاء كان وما لم يشأ لم يكن، له الخلق والأمر (27). 


\section{2- توحيد الألوهية:}

معناه الإعتقاد الجازم بأن الله سبحانه هو الإله الحق، ولااله غيره، وافراده سبحانه بالعبادة: أن الإله هو المألوه: أي المعبود (28) لا اله غيره، وافراده سبحانه بالعبادة فهي إنقياد لمنهج الخالق المشرع في الأمر والنهي في الحلال و الحرام وطلب المغفرة والطاعة من عنده تعالى، اذ ان مقتضى الإيمان باله ان يخلص العبد في عبادته ربه، ويخرج من الخضوع لهواه الى الخضوع لمولاه لما في ذلك من خير يلحقه، وطيب يرزقه(29)، وكذلك يشمل العبادة كالدعاء والذبح والنذر والصلاة والرجاء والخوف والاستعانة والتو كل وغيرها(30). ويجمع ابن القيم: توحيد الربوبية والألوهية بقوله: (فالجمع الصحيح الذي عليه أهل الاستقامة هو جمع توحيد الربوبية وجمع توحيد الألوهية)(31). وتوحيد الألوهية فهو إفراد الخالق عز وجل واختصاصه بسائر العبادات الظاهرة والباطنة قولاً وعملاً دون غيره، ونفي العبادة عن كل ما سوى الله كائناً من كان، وعدم الاشتراك به في أي شيء من صورها ودون أن يتوجه بشيء منها المى غيره أبداً. وإن أهم يقتضيه توحيد الالوهية التسليم التام للكتاب والسنة فلا بد من: أولاً: توحيد الله سبحانه وتعالى بالعبادة والخضوع والطاعة وبهذا تتحقق شهادة أن لااله الا الله. ثانياً: متابعة الرسول والاذعان لما أمر به ونهى عنه، وبهذا تتحقق شهادة أن محمداً رسول الله (32). 3- توحيد الأسماء والصفات:

و هو إفراد الله تبارك وتعالى بأسمائه وصفاته، بحيث يؤمن العبد بها أثبت الله لنفسه في كتابه، أو أثبته له رسوله من الأسماء والصفات، على الوجه الذي أراد الله ورسوله، وعلى الوجه اللائق به، من غير إثبات مثيل له، لأن إثبات المثيل لله تعالى شرك به(33)، ان توحيد الأسماء و الصفات يقوم على ثلاثة أسس، من حاد عنها لم يكن موحدا ربه في أسمائه وصفاته: - مواته الأول: تنزيه الله جل وعلا عن مشابهة الخلق، وعن أي نقص. الثاني: الإيهان بالاسماء والصفات الثابتة في الكتاب والسنة، دون تجاوزها بالنقص منها أو الزيادة عليها أو تحريفها أو تعطيلها. 


\section{الثالث: قطع الطمع عن ادراك كيفية هذه الصفات(34).

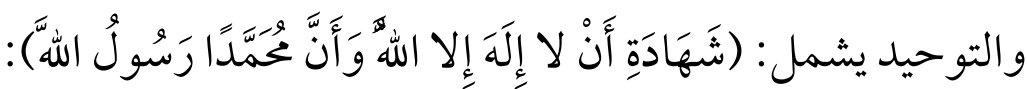
الشهادة تعني العلم والاعلام والأخبار والبيان ولهذا سمي الشاهد شاهداً لأنه يخبر بها علم، والبيان والأخبار كما يكون بالقول يكون بالفعل، وتتضمن كلمة الشهادة الإقرار والإعتر اف والإعتقاد فإن الشاهد يعتقد صحة ما يشهد به ويخبر عنه، فإذا شهد بها لايعتقده كانت شهادته كاذبة لأن أخباره لايطابق اعتقاده(35)، والإسلام جاء ليصحح العقائد الباطلة كافة ويعيد بني آدم الى الصراط المستقيم في العقائد والعبادات والشرائع (36). و اللسان ويترتب عليها طاعة الله والإلتزام بأو امره كالجهاد و إجتناب ما نهي عنه، كالقتل والزنى وغيرهما(37). عقيدة التوحيد في الإسلام:

1 - الإيهان بوجود الله، الأول والآخر والمحيي والمميت وهو على كل شىء قدير. وركن أساسي في العقيدة الإسلامية، ويؤمن الإنسان المسلم بأن الله سبحانه وتعالى واحد متفرد بالخلق والتدبير، لا يشاركه في خلقه وسلطانه وعزته أحد، وأنه جل شأنه هو الفعال المتصرف وهو رب كل شيء ومالكه وخالقه ومتفرد باستحقاق العبادة والتقديس ولا يستعان إلا به ولايخضع إلا اليه ولا يحاثله في أسمائه وصفاته أحد (38).

وهو أن يعتقد الإنسان بوجوده ووحدانيته وأنه لامثيل له ولا شبيه، وأنه متفرد بكل صفات الكمال ومنزه عن كل صفات النقص (39). بأنه واحد أحد فرد صمد لم يلد ولم يولد ولم يكن له كفوا أحد، والإيحان بأمره ونهيه ووعده ووعيده وثوابه وعقابه وعلمه المحيط بكل شيء وقدرته على كل شيء، والإيهان بربوبيته و ألوهيته وأسمائه وصفاته وأنه تعالى ير انا ويسمعنا ويعلم سرنا وعلانيتنا(40). 2- الإيهان بالملائكة: الملائكة أجسام نورانية لهم قوة خارقة لا تدانيها قوة البشر، ولهم وظائف يؤدونها بصدق وإخلاص(41). الإييان بملائكته الكرام البررة عموما وخصوصا (جبريل وميكائيل وإسرافيل(42) وملك الموت) وملائكة موكلون بإعداد الجنة لأهلها، وملائكة موكلون بإيقاد النار

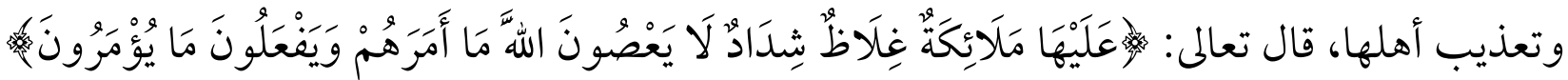


(التحريم: 6 ). وليس في السماوات السبع موضع قدم ولا كف ولا شبر إلا وفيه ملك قائم أو ملك راكع

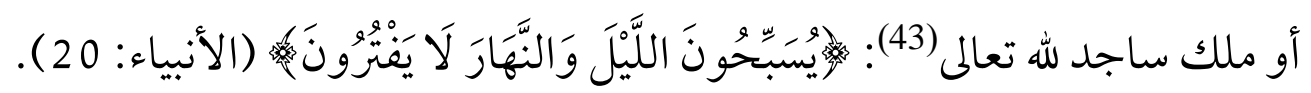

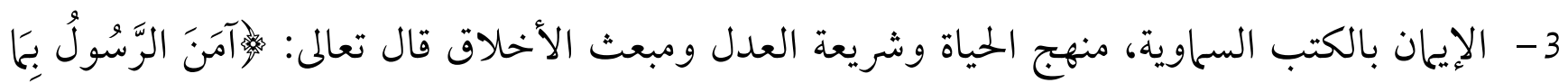

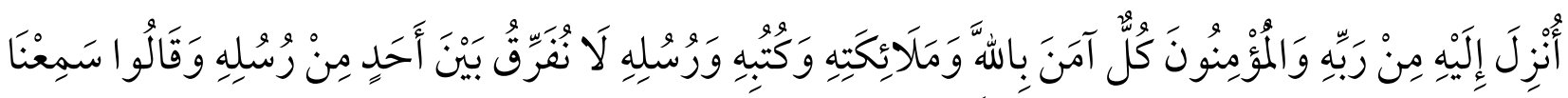

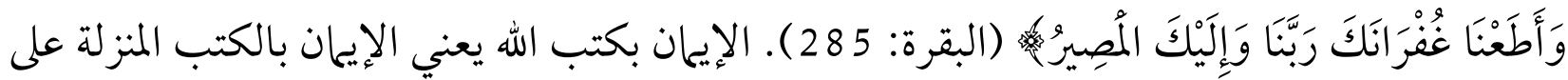

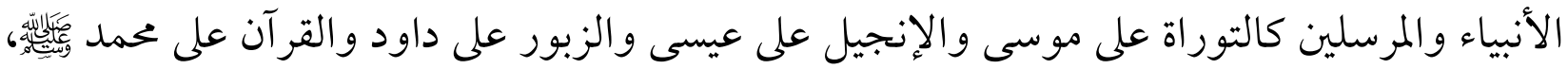
وهو أفضل الكتب السماوية والمهيمن عليها وناسخها وفيه تبيان لكل شيء وهدى ورحمة وشفاء لما في

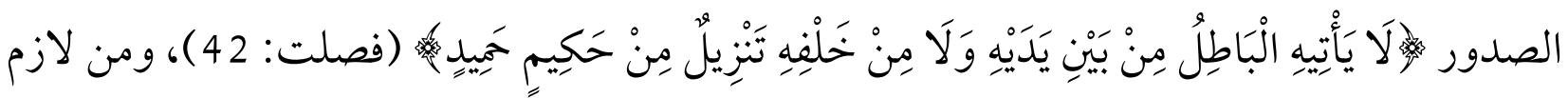
الإيهان به تلاوته وتدبره والعمل به فما آمن بالقرآن من استحل محارمه(44)، وقد دعانا الإسلام الى تصديق بهذه الكتب وبجميع ما أنززل جملةً (45). 4- الإيهان بالرسل الدعاة الم الله يبلغون الرسالة وئؤدون الأمانة ويجاهد في الله ويرشدون الم طريق المستقيم. الأنبياء هم صفوة الناس وخيرة الله في خلقه، والنبوة رياسة على الخلق اجمعين، من قبل الله تعالى، وهي موهبة ربانية لاتدرك بالجد والتعب ولاتنال بكثرة الطاعات والعبادة، أما الرسول فهو من أوحى الله اليه بشرع وأمره بتبليغه للناس (46). 5- الإيحان بالقضاء والقدر خيره وشره من الله تعالى والذي فيه معنى الرضا والتسليم بها كتب الله وقدر:

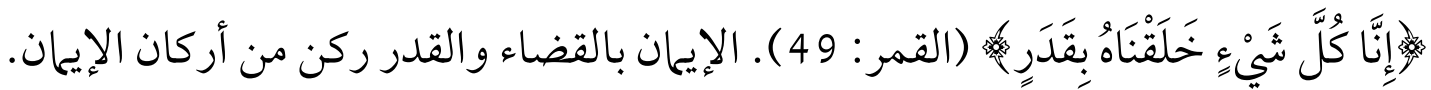
القضاء: هو علم الله المحيط بما كان وما يكون وما هو كائن المى يوم الحساب والجزاء. والقدر: هو وقوع الحو ادث في الأزمنة والأشخاص طبقاً لما في علم الله جلّت حكمته. ومعنى الإيـان بها هو: الإعتقاد بأن ما يصيب الإنسان من خير أو شر واقع حسب تقدير الله تعالى وعلمه. 
ومما يجدر التنبيه عليه أن علم الله بما سيقع من عباده ووقوعه منهم حسب هذا العلم و التقدير، لا يعني أن العباد بجبرون في أفعاهم، ملزمون بالإتيان بها وإلا بطل الثواب والعقاب، والأمر والنهي والوعد والوعيد، بل الإنسان هو الذي يخط أفعاله بنفسه متخذاً الطريق الذي يراه(47). 6- الإيهان باليوم الآخر: من الأمور المسلم بها في الدين الإسلامي الإعتقاد بحياة أخرى بعد الموت، يبعث الناس بعد موتهم ويحاسبون على ما قدّموا من أعمال، فيجاوزون عليها، وسمي باليوم الآخر لأنه آخر أيام الدنيا، بمعنى أنه متصل بآخر أيام الدنيا، لأنه ليس منها حتى يكون آخرها، وسمي بيوم القيامة لقيام الناس فيه من قبورهم، وقيامهم بين يدي خالقهم والإيهان باليوم الآخر ركن من أركان الإيمان

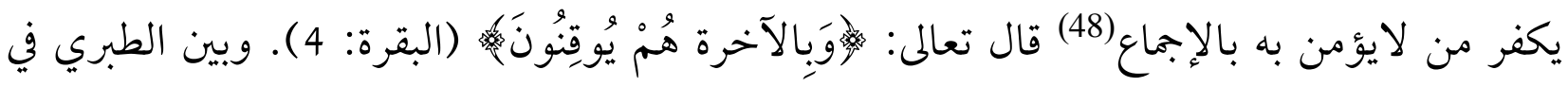
تفسيره لقوله تعالى: (وبالآخرة هم يوقنون) بأن الآخرة سميت بهذا الإسم لتأخرها، وسميت دنيا لدنوها من الخلق، لقد عرف القرآن الكريم اليوم الآخر بعدة تعريفات فهو: يوم القيامة يوم الحساب القارعة الغاشية الحاقة،ان قضية الإيهان باليوم الآخر والبعث والنشور من قضايا العقيدة الإسلامية الأساسية، بعد الإيهان بوحدانية الله تعالى والتي لا يقوم هذا الدين الا عليها ولا يكمل الإيهان الا بها، ذلك لأن الإيحان بالله تعالى يعرفنا بمصدر هذا الكون وخلقه والإيهان باليوم الآخر يعرفنا بمصيره ونهايته (49).

\section{المطلب الثاني: الديانة المسيـحية:}

الديانة المسيحية: هي الرسالة التي أُنزلت على عيسى عليه الصلاة والميلحيلة : الميلام، مكمّلة لرسالة موسى عليه الصلاة والسلام، ومتممة لما جاء في التوراة من تعاليم، موجهة إلى بني إسرائيل، داعية إلى التوحيد والفضيلة والتسامح، ولكنها جابهت مقاومة واضطهاداً شديداً، فسرعان ما فقدت أصولها، مما ساعد على إمتداد يد التحريف إليها، فابتعدت كثيراً عن أصولها الأولى لامتزاجها بمعتقدات وفلسفات وثنية(50). 


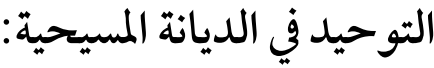

عندما نصل الى الحديث عن التوحيد في التفكير المسيحي نحتاج الى مزيد من الصب لنرى التحول الخطير

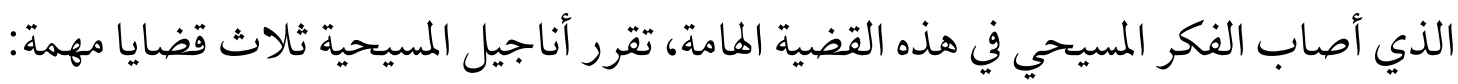
ان الله واحد لاشريك له. أن عيسى رسول الله وليس أكثر من رسول. أن عيسى رسول لبنى اسر ائيل فقط.

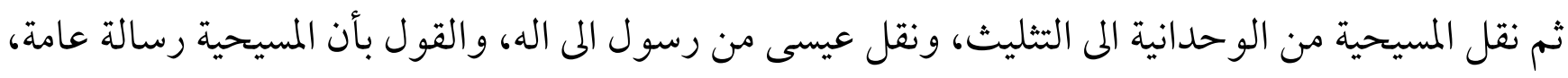
و القول بأن عيسى هو ابن الله نزل ليضحي بنفسه للتكفير عن خطيئة البشر، وأنه عاد مرة أخرى الى السماء

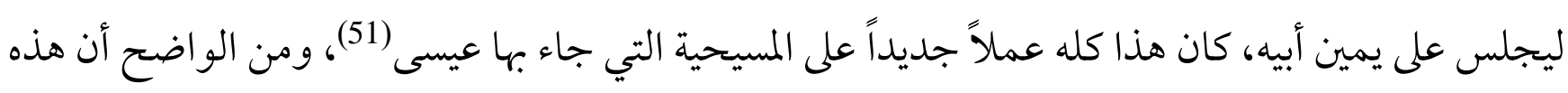
العقيدة تختلف تماماً عن عقيدة النصارى التي جاء بها المسيح عليه السلام، ثم ابدلت الديانة المسيحية، واحذف الفكر المسيحي. التوحيد في المسيحية الإيهان باله الو احد، الأب مالك كل شيء، وصانع ما يرى وما لا يرى، هكذا في قانون

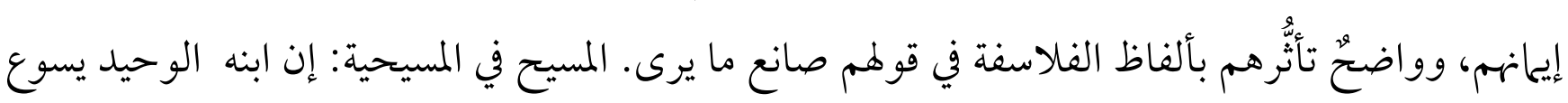

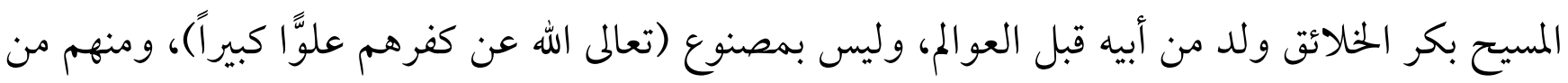
يعتقد أنه هو الله نفسه (سبحانه وتعالى عن إفكهم) وقد أشار القرآن الكريم إلى كلا المذهبين، وبيَّن فسادهما،

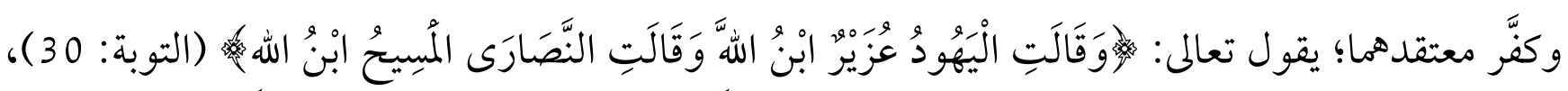

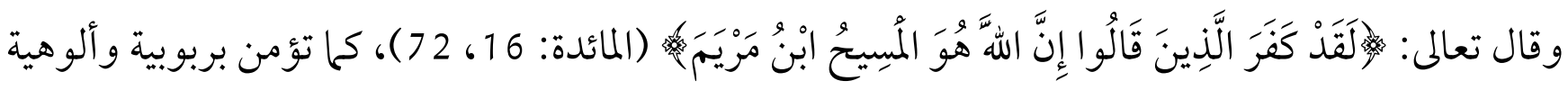
الرب والمسيح في آن واحد على أنها من جوهر واحد ومشيئة واحدة، ومتساويين في الأزلية، لكن كنيسة

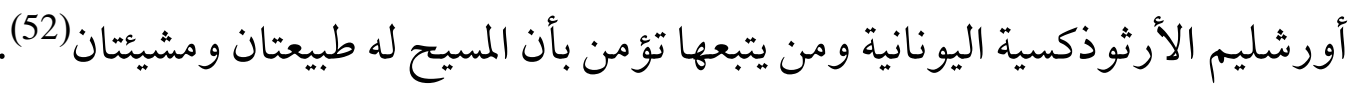

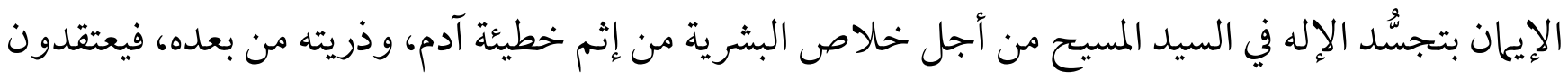

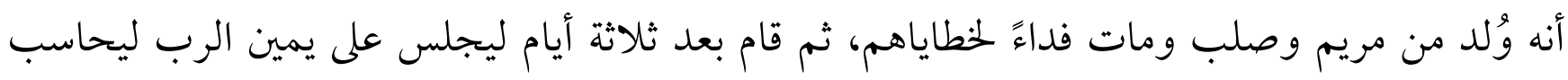
الخلائق يوم الحشر. الإيمان بأن السيدة مريم العذراء والدة الإله، ولذا يوجبون تقديسها كما يقدسون القديسين، والأيقونات غير المجسمة، وذخائر القديسين، ويقدسون الصليب، ويتخذونه رمزاً وشعاراً (53.). 
كانت دعوة المسيح الى التوحيد الخالص كدعوة سائر الأنبياء والمرسلين، والحواريون والتلاميذ الذين رفع عنهم المسيح كلهم كانوا على ذلك التوحيد، الى أن دخل بولس الرسول في المسيحية، ولم يكن هذا اليهودي المتعصب من تلاميذ المسيح أو حواريه، بل لم ير المسيح في حياته أبدا، ولم يسمع منه أي موعظة وكان عدواً لدوداً للمسيحيين ويصطهدهم على الإستمرار (54). ولأفانيم هي الأصل الأول من أصول النصرانية واعظم اسرارها، ويحدّه اللاهوتيون بقوهم: (الإله الواحد في ثلاثة اقانيم متميزين (آب وابن وروح قدس) كل أقنوم قائم بذاته طبيعتهم واحد وجوهرهم واحد، فكلمتا الثالوث والأقانيم متر ادفتان، وعقيدة الثليث تعتبر أهم ركن من أركان النصر انية، ولا يعتبر الشخص نصر انياً الاّّاذآ آمن بهذا الثالوث)(55). عقد بمع نقية سنة 325 ضم جميع الطوائف المسيحية في الشرق والغرب واتفق الجميع بعد المدارسة والمناقشة على الخطوط الرئيسية للمسيحية من ناحية العقائد واتفقوا على: الإعتراف بالثالوث: الاب والابن والروح القدس، شعاراً للمسيحية، والإيهان بأن المسيح جاء لتخليص العالم من خطيئة آدم المتوارثة(56). ففكرة التعدد والتجسيد وحلول الإلهة وتجسيده بالناسوت يعرفها الفكر الوثني منذ غابر العصور، وكل هذه الأفكار دخلت الى النصر انية بعد انخر اطها في ذلك المجتمع الوثني (57). من معتقدات المسيحية:

1 - الثثليث في المسيحية: لقد استقر أمر النصارى على عقيدة التثليث بعد بجمع نيقيا الذي عقد في 325م وكان المسيحيون مختلفين في هذه العقيدة، كلمة الثثليث مشتقة من الثلاث قال تعالى:

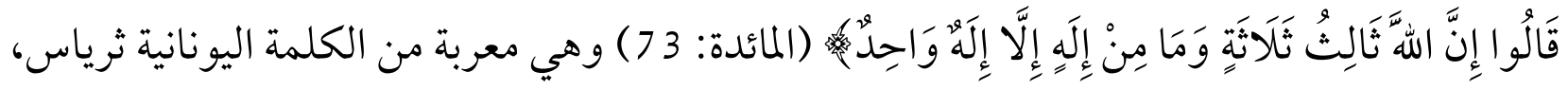
اما معنى التثليث عند المسيحية طبيعة الله عبارة عن ثلاثة اقانيم متساوية: الله الاب الله الابن الله روح القدس فإلى الاب ينتمي الخلق والى الله الابن الفداء والى الله روح القدس التطهير(58) داخل المسيحية، هناك التوحيديون الذين يؤمنون بأن الهه يتكون من شخص واحد فقط، هو الأب، بدلاً من ثلاثة أشخاص كالمذهب الثالوثي. 
2- صلب المسيح للتكفير عن خطيئة البشر: هذا هو أساس الثاني من أسس العقيدة المسيحية، أساس هذا الموضوع عند المسيحيين ان من صفات الله العدل والرحمة وبمقتضى صفة العدل كان على الله أن يعاقب ذرية آدم بسبب الخطيئة التى ارتكبها أبوهم وطُرد بها من الجنة واستحق هو وابناؤه البعد عن الله بسببها، وبمقتضى صفة الرحمة كان على الله ان يغفر سيئات البشر، وأن ابن الإنسان قد جاء ليخلص ما قد هلك فبمحبته ورحته قد صنع طريقا للخلاص، لذذا كان المسيح هو الذي يكفر عن خطايا العالم. 3- المسيح يحاسب الناس: هذا هو أساس الثالث من أسس العقيدة المسيحية، ويرى المسيحيون ان الأب أعطى سلطان الحساب للابن، وذلك لأن الابن بالإضافة المى الوهية وابديته ابن الإنسان أيضاً، فهو أولى بمحاسبة الإنسان، ويعتقدون انه بعد أن ارتفع الى السلاء جلس بجوار الأب على كرسي استعدادا لاستقبال الناس يوم الحشر (59). 4- يؤمن المسيحيون ان الروح القدس قد حلّ على مريم العذراء لدى البشارة ليتم الحمل يسوع، وحل على المسيح في العماد في نهر الأردن، وحل على الرسل بعد صعود المسيح الم السماء، كما يعتقد المسيحيون أن روح القدس لايز ال موجوداً وهو ينزل على الآباء والقديسين في الكنيسة ويرشدهم (60). من الملاحظ: لا يوجد نص واحد في الكتاب المقدس يصرح فيه المسيح بألوهيته أو يطلب من الناس عبادته، كما لم يعبده أحد من معاصريه، ولعدم الدليل الصحيح الصريح على الوهية المسيح جعل النصارى يحرفون في طبعات الأناجيل الجديدة(61). 5- الصليب: يعتبر الصليب شعاراً لهم وهو موضع تقديس الأكثرين، وحمله علامة على أنهم من أتباع المسيح، ولا يخفى ما في ذلك من خفة عقولهم وسفاهة رأههم، فمن الأولى لهم أن يكرهوا الصليب ويحقروه لأنه كان أحد الأدوات التي صلب عليه إلههم وسبب آلامه. وعلى حسب منطقهم فكان الأولى بهم أن يعظمو اقبره الذي زعموا أنه دفن فيه، ولا مس جسده تربته فترة أطول مما لامس الصليب. 6- مريم البتول: يعتقد النصارى على ما أضيف في قانون الإيمان أن مريم ابنة عمران والدة المسيح (عليه السلام)، هي والدة الإله، ولذا يتوجَّه البعض منهم إليها بالعبادة(62.). 
7 - الدين: يؤمن النصارى بأن النصرانية دين عالمي غير غختص ببني إسرائيل وحدهم (63).

8 - الأسرار السبعة: والتي ينال بها النصراني النعم غير المنظورة في صورة نعم منظورة، ولا تتم إلا على يد كاهن شرعي، ولذا فهي واجبة على كل نصراني ممارستها وإلا أصبح إيانه ناقصاً، وبالجملة فانها من ضمن التشريعات التي لمُينزل الله بها من سلطان، وإنها هي من تخرُّات البابوات. 1 - سر التعميد: ويقصد به تعميد الأطفال عقب ولادتهم بغطاسهم في الماء أو الرش به باسم الأب والابن والروح القدس، لتمحي عنهم آثار الخطيئة الأصلية، بزعم إعطاء الطفل شيئاً من الحرية والمقدرة لعمل الخير، وهذا أيضاً على خلاف بينهم في صورته ووقته.

2- سر التبيت (الميرون): ولا يكون إلا مرة واحدة، ولا تكمل المعمودية إلا به، حيث يقوم الكاهن بمسح أعضاء المعتمد بعد خروجه من جرن المعمودية في ستة وثلاثين موضعاً - الأعضاء والمفاصل بدهن الميرون المقدس.

3 - سر العشاء الرباني: ويكون بالخمر أو الماء ومعه الخبز الجاف حيث يتحول في زعمهم الماء أو الخمر إلى دم المسيح، والخبز إلى عظامه، وبذلك فإن من يتناوله فإنما يمتزج في تعاليمه بذلك، وكذلك فقرقُهم على خلاف في الاستحالة بل وفي العشاء نفسه. 4- سر الإعتراف: وهو الإفضاء إلى رجل الدين بكل ما يقترفه المرء من آثام وذنوب، ويتبعه الغفران والتطهير من الذنب بسقوط العقوبة، وكان الإعتراف يتكرر عدة مرات مدى الحياة، ولكن منذ سنة 1215م أصبح لازماً مرة واحدة على الأقل، وهذه الشعيرة عندهم أيضاً مما اختّلفف في وجوبها و وإسقاطها. 5 - سر الزواج: يُسمح الزواج بزوجة واحدة مع منع التعدد الذي كان جائزاً في مطلع النصرانية، ويُشترط عند الزواج حضور القسيس ليقيم وحده بين الزوجين، والطلاق لا يجوز إلا في حالة الزنى - على خلاف بينهم - ولا ييوز الزواج بعده مرة أخرى، بعكس الفراق الناشئ عن الموت، أما إذا كان أحد الزوجين غير نصراني فإنه يجوز التفريق بينها. 
6- سر مسحة المرضى: وهو السر السادس بزعم شفاء الأمراض الجمدية المتسببة عن العلل الروحية وهي الخطيئة، ولا يحارس الكاهن صلوات القنديل السبع إلا بعد أن يتثَّت من رغبة المريض في

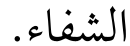

7 - سر الكهنوت: وهو السر الذي ينال به الإنسان بزعمهم النعمة التي تؤهِّله لأن يؤدي رسالة السيد المسيح بين إخوانه من البشر، ولا يتم إلا بوضع يد الأسقف على رأس الشخص المنتخب ثم يتلى عليه الصلو ات الخاصة برسم الكهنة(64).

\section{المطلب الثالث: الديانة اليهودية:}

اليهودية: (هي ديانة العبرانيين المنحدرين من إبراهيم (عليه السلام) والمعروفين بالأسباط من بني إسرائيل الذي أرسل الله إليهم موسى عليه السلام مؤيداً بالتوراة ليكون لهم نبيًّ. و اليهودية ديانة يبدو أنها منسوبة إلى يهود الشعب. وهذه بدورها قد اختلف في أصلها. وقد تكون نسبة إلى يهوذا أحد أبناء يعقوب وعممت على

$$
\text { الشعب على سبيل التغليب)(65). }
$$

الديانة اليهودية في أصلها ديانة سماوية تؤمن بالتوحيد وتتصف فيها الذات الإلهية المقدسة بصفات الوحدة و الكمال والتجرد عن كل صفات النقص كما هو الحال في الديانة الإسلامية، لكن من خلال تأريخها الطويل تراكمت فيه طبفات اخرى تطرح تصورات مختلفة عن الإله. لم يستطيع بنو اسرائيل في أي فترة من الفترات تأرخهم أن يستقروا على عبادة الله الواحد الذي دعا له الأنبياء، وكان اتجاههم الى التجسيم والتعدد والنفعية واضحاً في جميع مراحل تأريخهم، وكثرة انبيائهم دليل على تجدد الشرك فيهم، وبالتالي تجدد الحاجة المى أنبياء يجددون الدعوة المى التوحيد(66). امتاز تأريخ الإله عند اليهود بعدم الاستقرار اذ مرت عقيدتهم بمرحلتين: الأولى: مرحلة التفريد والتي تمجد الإله (يهوه) كأن هناك آلمة أخرى كثيرة في العالم. الثاني: التوحيد المطلق لله تعالى التي عزز ما في نفوسهم موسى (عليه السلام) ولكنهم سرعان ما تنكروا لما بعد وفاته (67)، يظهر من التأمل في أقدم سفرين من أسفار 
التوراة ومما سفر التكوين والخروج: ان فكرة الألوهية ظلت مضطربة في عقولهم المى نهاية المرحلة التي تم فيها تدوين السفرين (اي الى ما بعد موسى) بأربعة قرون فصوروا الله في صورة ججمة ووصفوه بكثير من الصفات التي لا تليق به كالنقص و الضعف و الكذب(68)، جاء في التوراة و التلمود وصف الله تعالى بها لا يليق به سبحانه وتعالى من صفات النقص والتجسيم، فصوروا الله في صورة مجسمة، وأن اليهود على مدى تأريخهم الطويل دائحً يعبدون آلهةً غير الله سبحانه وتعالى فقد عبدوا العجل والأصنام والأوثان، وأن التوحيد الخالص الذي جاء به موسى عليه السلام لا تجده عند اليهودعلى مدار تأريخهم (69)، إذن في الأصل يؤمنون بإله واحد خالق الكون، والمعبود الحق، وأول أربع وصايا من الوصايا العشر تؤكد أهمية التوحيد، الأول عن وجود الله وحده، والثاني عن عدم اتخاذ إله آخر مع الله، والثالث عن عدم اتخاذ صورة أو تمثيل لله أو عن الله، والرابع عدم التلاعب باسم الله أو تشبيهه بأي شي آخر، الذي يؤمن به اليهودية بأنهم شعب الله المختار، وأنهم جميعا ناجون لمجرد هذا الميثاق الذي تم بين الله وبين أبيهم إبراهيم عليه السلام، والمبني على ميثاق عرقي وعنصري لا ميثاق عمل وطاعة، ناهيك على قصص كثيرة في التوراة، لا تستقيم مع قوة الله وكماله وتوحيده. مثلاً من صفاته كذلك في التوراة المحرفة الحالية والتي لا تليق بجلاله عز وجل أنه يغار من بقية الإلهة وأنه ينام ويستيقظ، وقد تعب من خلقه للكون فاستراح يوم السبت(70)، جاء في سفر التكوين الاصحاح الثاني الفقرة 2: (وفرغ الله في اليوم السابع من عمله الذي عمل فاستراح في اليوم السابع من جميع عمله الذي عمل، لذذا

$$
\text { فيوم السبت مقدس تجب فيه الراحة)(71). }
$$

1 - اتخذوا العجل معبوداً له بُعَيْد خروجهم من مصر، ويروي العهد القديم أن موسى قد عمل لهم حية من نحاس وأن بني إسرائيل قد عبدوها بعد ذلك، كما أن الأفعى مقدس لديهم لأنها تمثل الحكمة والدهاء.

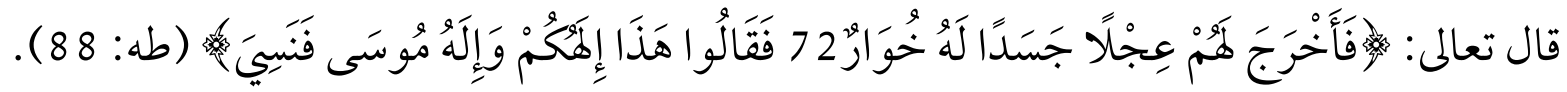


2- الإله لديهم سموه يهوه وهو ليس إلهاً معصوماً بل يخطئ ويثور ويقع في الندم وهو يأمر بالسرقة، وهو

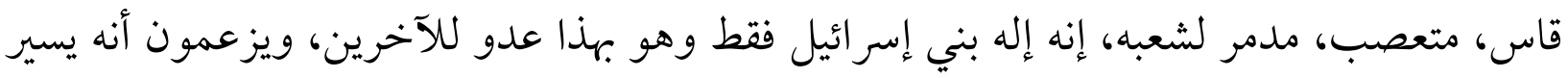

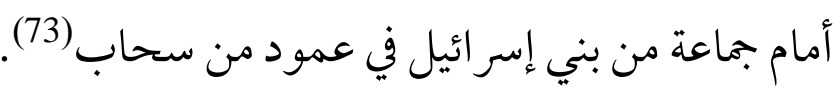

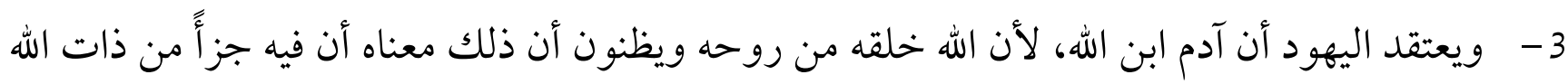
كما يعتقدون أن الله خلق آدم على صورة الله، ومع ذلك أنجبت حواء من آدم بجموعة من الأبناء والبنات، ولذلك فإن أبناء آدم وحواء هم ابناء الله، ويقول التلمود (تتميز أرواح اليهود عن باقي الأرواح بانها جزء من الله كما أن الابن جزء من والده ... وأن أرواح اليهود عزيزة عند الله لأن أرواح غير اليهود هي أرواح شيطانية..) ويقول الفرق بين درجة الإنسان والحيوان كالفرق بين اليهودى

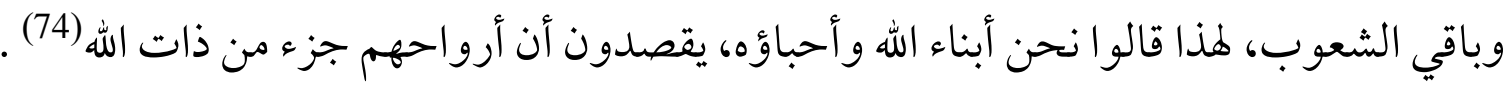
4- ويقولون: (أن الله يهجل ما يحدث ولم يعرف ان آدم أكل من شجرة المعرفة إلا بعد أن اختبأ آدم واخبره بذلك، فرات المراة ان الشجرة جيدة للاكل وانها بهجة للعيون وان الشجرة شهية للنظر فاخذت من ثمرها واكلت واعطت رجلها ايضا معها فاكل، فانفتحت اعينها وعلم) انها عريانان فخاطا اوراق تين و صنعا لانفسهما مازر) (1)

5- النبي أرميا يصف الله بالخداع: يقول أرميا النبي للرب: (فقلت آه ياسيدي الرب، حقاً انك خدّاع

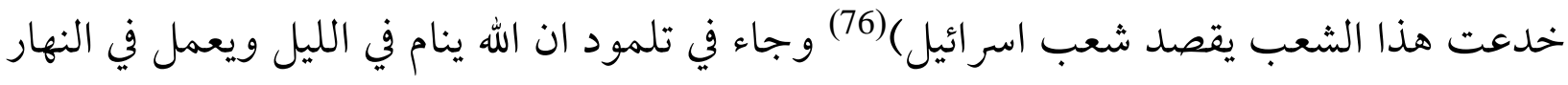
ويتدارس التوراة ويلعب مع الحوت ملك الأسماك (77). 6- الرب يصارع يعقوب: جاء في التوراة المحرفة سفر التكوين: (بقى يعقوب وحده وصارعه انسان حتى

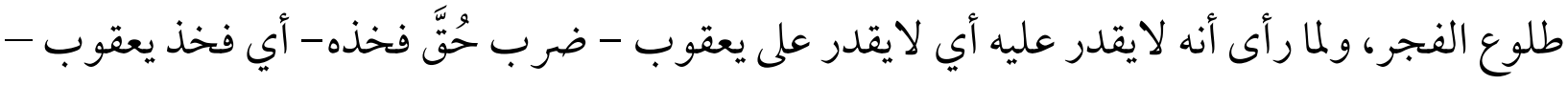

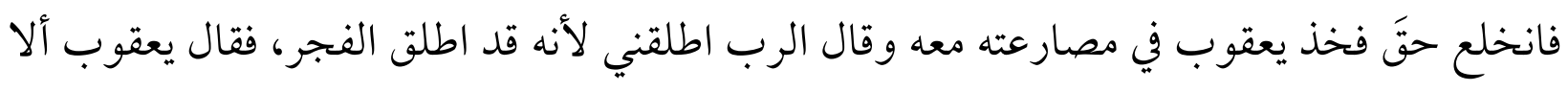
اطلقك ان لم تباركني فقل له الرب مااسمك فقال يعقوب فقال الرب: لا يدعني اسمك فيا بعد 
يعقوب بل اسرائيل لأنك جاهدت (أي صارعت) مع الله والناس فقدرت.وقال يعقوب أخبرني باسمك؟ فقال الرب لماذا تسأل عن اسمي؟ وباركه هناك .. (78). 7- الكتاب المقدس ينسب الى موسى إساءة الأدب والسفاهة في كلامه مع الله، جاء في سفر الخروج:

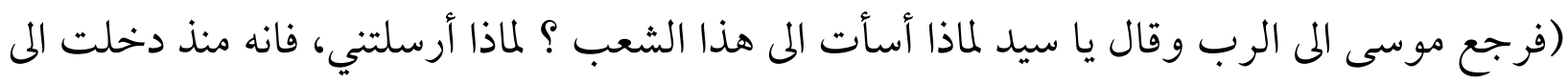

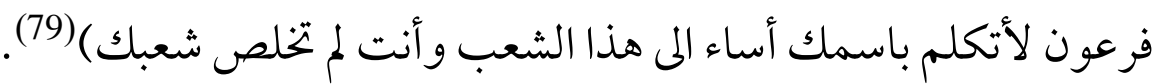

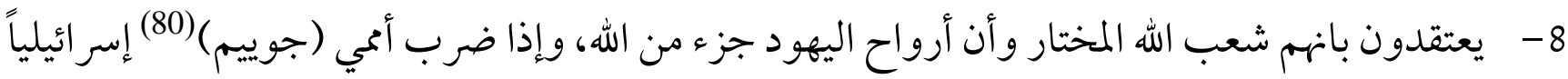
فكأنما ضرب العزة الإلهية، وأن الفرق بين درجة الإنسان والحيوان هو بمقدار الفرق بين اليهودي وغير

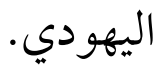

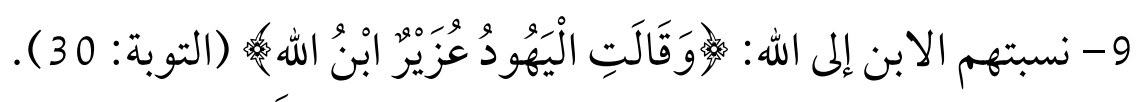

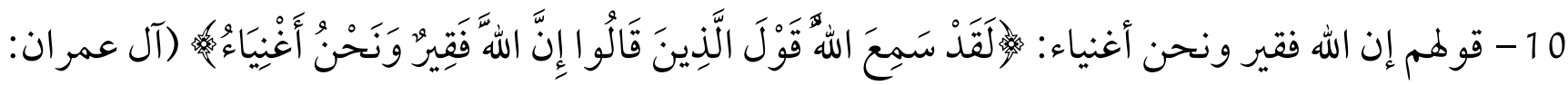

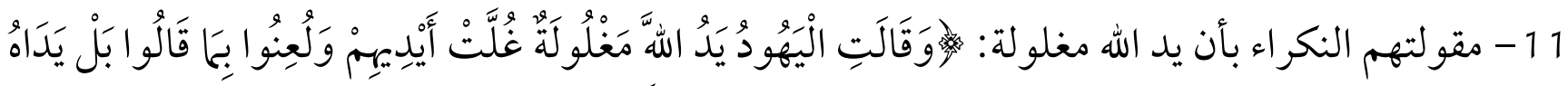

$$
\text { مَبْسو طَتَانِ (المائدة: } 64 \text { ). }
$$

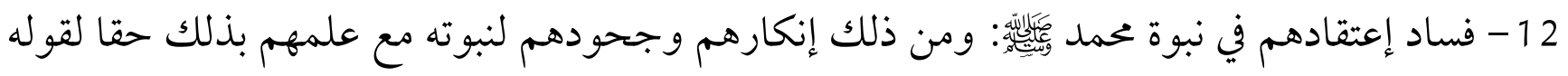

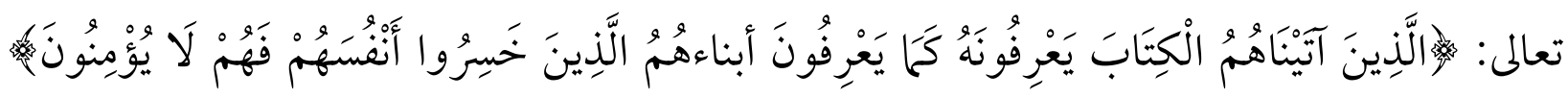

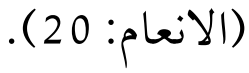
13 - إفتراؤهم على المسيح وأمه مريم وقولمم عليها بهتاناً عظياً(81) وغير ذلك من الافتراءات على الله

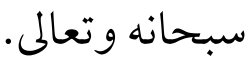




\section{المطلب الرابع : الديانة الهندية:}

تدل الدراسات الدينية على تعدد المعبودات والمعتقدات في الديانات الهندية وتنوعها حتى أطلق عليها اسم أرض الإلمة. واختلفت الديانة من منطقة لأخرى وتعددت المعبودات في المنطقة الو احدة(82).

\section{التوحيد في الديانة المندوسية:}

التوحيد: لا يوجد توحيد بالمعنى الدقيق، لكنهم إذا أقبلوا على إله من الإلهة أقبلوا عليه بكل جوارحهم، حتى تحتفي عن أعينهم كل الإلهة الأخرى، وعندها يخاطبونه برب الأرباب أو إله الإلهة. وأن (برهما) هو الحقيقة المطلقة وهو الإله الأزلي. فهم يرون أن الخلاص الحقيقي يتم بالاتحاد به. وهذا جزء من مبدأ الجزاء عندهم الناتج عن إيهانهم بالتناسخ، حيث لا يؤمنون بالآخرة، التعدد: يتجه التفكير الهندوسي فيا يختص بالإله الى لي نزعة التعدد غالباً وقد بلغ التعدد عند الهنود مبلغا كبيراً، فقد كان عندهم لكل قوة طبيعية اله يعبدونه ويستصرون به في الشدائد كالماء والنار والجبال وغيرها، وكانوا يدعون تلك الإلهة لتبارك لهم في ذريتهم وأمو الهم من المواشي والثمار وتنصرهم على أعدائهم (83) تعدد الإلهة هي النزعة الأرسخ وجوداً والأبرز مظهراً والاطغى حضوراً في فكر الهندوس الديني. تدل الدراسات الدينية على تعدد المعبودات والمعتقدات في الديانات الهندية وتنوعها حتى أطلق عليها إسم أرض الإلمة. واختلفت الديانة من منطقة لأخرى وتعددت

$$
\text { من معتقدات الديانة المندوسية: }
$$

1 - التثليث: في القرن التاسع قبل الميلاد جمع الكهنة الإلهة في إله واحد أخرج العالم من ذاته، وهو الذي

$$
\text { إسموه: }
$$

أ- برهما: وهو الإله الخالق مانح الحياة القوي الذي صدرت عنه جميع الأشياء والذي يرجو لطفه وكرمه جميع الأحياء، وينسبون اليه الشمس التي بها يكون الدفء وانتعاش الأجسام، وتجري الحياة

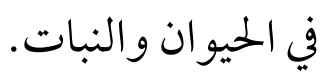

ب- سيفا: وهو الإله المخرب المفني الذي تصفر به الأوراق الخضر اء ويأتي الهرم بعد الشباب. 
ج- فشنو: ان فشنو هذا حل في المخلوقات ليقي العالم من الفناء التام. وهذه الإلهة الثلاثة أقانيم اله واحد في زعمهم والإله الواحد هو الروح الأعظم واسمه بلغتهم (آتما)(85).

فمن يعبد أحد الإلهة الثلاثة فقد عبدها جميعاً، أو عبد الواحد الأعلى، ولا يوجد أي فارق بينها. وهم بذلك قد فتحو ا الباب أمام النصارى للقول بالثثليث(86). 2- يلتقي الهندوس على تقديس البقرة وأنواع من الزواحف كالأفاعي، وأنواع من الحيوان كالقردة، ولكن تتمتع البقرة من بينها جميعاً بقداسة تعلو على أي قداسة، ولها تماثيل في المعابد والمنازل والميادين، ولها حق الانتقال إلى أي مكان، ولا يجوز للهندوكي أن يمسها بأذى أو بذبحها، وإذا ماتت دفنت بطقوس دينية، ففي الويدا حديث عن قداستها والصلاة لها، رأى غاندي في عبادة البقرة: يقول: (عندما أرى بقرة لا أجدني أرى حيو انا، لأني أعبد البقرة وسأدافع عن عبادتها أمام العالم أجمع...وإن ملايين الهنود يتجهون لها بالعبادة والإجلال وانا أعد نفسي واحداً من هؤلاء الملايين)(87) ولقد عبد الهندوس الحيوان على اعتباره جداً حقيقياً أو رمزياً للأسرة ثم للقبيلة، وأمنوا بتناسخ الأرواح فجاز عندهم أن يكون الحيوان جداً قديماً. وكثرة عبادة التماثيل الى جانب عبادة الحيوانات(88). 3 - يعتقد الهندوس بأن آهنهم قد حلَّت كذلك في إنسان اسمه كرشنا، وقد التقى فيه الإله بالإنسان، أو حل اللاهوت في الناسوت، وهم يتحدثون عن كرشنا كما يتحدث النصارى عن المسيح (89). 4 - جملة ما يقال فيها وتشير اليه ان أقوام هذه الديانة عبادة النيران، فانها كانت المعبود المقدس الذي تقدم اليه القرابين من خبز وأعشاب وخمر، ويتولى الكهنة وهم سدنة معابد النيران، القيام بها يقتضيه التقديس من طقوس ورسوم في تلك الديانة، ولم تكن النار الإله المتفرد بالألوهية بل كانت يشاركها في التقديس آلهة أخرى منها الشمس، لما تفيض به على الكون من أشعة مضيئة وحرارة منعشة للأجسام ومنها

$$
\text { حيو انات خخيفة(90). }
$$

5 - عقيدة الحلول والإتحاد: كانت هذه العقيدة سائدة في الهند منذ عهد بعيد(91).

6 - لاعتقادهم بفكرة التناسخ فزعمو ا أن أي حيو ان ممكن أن يكون أحد اقربائهم أو أصدقائهم القدماء(92. 
وجدير بالاشارة أن ايحان الهندوسية بتعدّد الإلهة وبالثالوث المقدس (براهمان وفشنو وشيفا) الذي يرأس هذا التعدّد الإلهي كان ضرورة قصوى بسبب الفوضى التي عمّت العالم ولتحقيق الحق والعدل. ويختزل الهندوس كل هذه الإلهة في ثلاثة آلمة أو في إله واحد ذو ثلاثة أقانيم أو معاونين: الإله براهمان: وهو الإله الخالق، لا هو مؤنث ولا هو مذكر، فالمعبود إذا خنثى، أي أنه يجمع بين التذكير والتانيث. وهو الخالق النزيه الذي لا ابتداء ولا انتهاء له، حرّ في خلقه أو هو الخالق و المخلوق، لا يشبه شيئاً ولا يشبهه شيء، خخيّر وغير مسيّر.

\section{المطلب الخامس: الديـانة الفارسيـة:}

لبلاد الفارس أديان كثيرة منها: الديانة الزرادشتية: ديانة كان تأسيسها في بلاد فارس في قرن السادس قبل الميلاد على يدي زرادشت بن يورشب الذي ظهر في عهد الملك كشتاسببن لهراسب، وتسمى المجوسية لأن قبيلة المجوس الفارسية هي أول من تبع الزرادشتية. هناك آلمة ترمز الى ظواهر طبيعية خختلفة، كآلةة الأرض والسماء، التي سماها الإيرانيون آسمان (السماء) وزام (الأرض) و آلهة الشمس (خور) (93). التوحيد في الديانة الزرادشتية: يختلف الباحثون حول طبيعة هذا الدين، فمنهم من يقول: أنه دين موحد وآخرون يجزمون بأنه دين ثنوي، لكن الغالبية العظمى منهم تتفق الى حد ما حول ثنوية هذا الدين (94)، يعتقدون أن أهور امازدا (Ahura Mazda) بمعنى الإله الحكيم هو الإله الأعظم؛ رغم إيهانهم بأن الحياة صراع بين قوتي الخير والشر؛ إلا أن العاقبة للخير، مما أبقى مفهوم التو حيد مشوها. ان المتأمل في الزرادشتيين يدرك ان الديانة الزرادشتية كانت في أصلها عقيدة تقوم على التوحيد المطلق والتنزيه الكامل للاله (اهورامزدا) أنه الإله الخالق لكل شيء القادر على كل شيء، الذي يعلم ما في السماوات والأرض وليس له شريك، ان عبارة (اهورامزدا) تدل على ذلك: فهو اسم مركب من ثلاث كلمات وهي (آهو -رامزدا) ومعناها على الترتيب (آنا-الوجود-خالق) أي وحدي خالق الوجود أو الكون.ولكن لم تبق الزرادشتية على التوحيد طويلا فلقد تحولت فيا بعد الى دين ثنوي يقوم على عبادة الهين اثنين هما (اهورامزدا واهريحان)، 
و الأول في زعمهم هو اله الخير ومبدأ الحياة وهو الذي خلق السماوات والأرض والملائكة والبشر، وكل ما هو خير ونافع، أما الثاني (اهريهان) فهو اله الشر ومبدأ الموت وصانع الشياطين والحيوانات المفترسة(95). فيقال: انه دعا الى التوحيد وأبطل الأصنام، وجاء بعده علم) سنوا للزر ادشتيين شرائع مختلفة فحرموا عليهم الإشتعال بالأشياء التى تلتزم النار، فاقتصروا في أعمالهم على الفلاحة والتجارة، ومن هذا التمجيد للنار واتخذها قبلة في العبادات تدرج الناس الى عبادتها حتى صاروا يعبدونها عينا ويبنون هياكل ومعابد. وتقوم العقيدة الزرادشتية على الثنوية(96). ولكن لم تبق الزرادشتية على التوحيد طويلا فلقد تحولت فيما بعد المى دين ثنوي يقوم على عبادة إلهين إثنين هما (أهورا مزدا وأهريحان)، والأول في زعمهم هو اله الخير ومبدأ الحياة وهو الذي خلق السماوات والأرض والملائكة والبشر وكل ما هو خير ونافع، أما الثاني (اهريهان) فهو اله الشر ومبدأ الموت وصانع الشياطين والحيوانات المفترسة(97)، لم تسلَم عقائد زرادشت من التبديل والتحريف و التغيير شأنها في ذلك شأن كثير من العقائد والديانات الأخرى فلم تبق تعاليمه وعقائده كما وضعها(98). من معتقدات الزرادشتية: - من 1 - يعتقد الزر ادشتيون بوجود اله للخير خالق يسمونه اهورامزدا ويقولون (انه اله النور والسم)ء وان غيره من الإلهة ليست الا مظاهر له، وصفات من صفاته وفي عقيدتهم هناك مصدر للشرك يسمونه (اهرمان) ومعناه: الخبيث أو القوى الخبيثة، وهو اله الظلمة وهو اله الظلمة، ولكنه ليس بمستوى أهورمزدا الخالق، وهناك صراع عندهم بين اله النور واله الظلمة لذلك اطلقت عليهم تسمية ثنوية، وآهرمن هو مصدر الشر والخالق اهورامزدا لايليق به ان يقال أنه خالق الشر، والمؤمنون واجبهم ان ينصروا اله (النور)(99)

$$
\text { 3- } 2 \text { - منع عبادة الجن والشياطين، وان العبادة لا تكون الا للخالق الو احد (اهورا مزدا). }
$$


5- و أنهم يقدسون النار ولايعبدونها لأنها مقدسة كرمز.تقسيم النار المى خمة أنواع: النار التي في بيوت الناس، النار التي تسري في جسد الإنسان والحيوان، النار التي تسري حرارتها في النبات، النار في الصواعق بين الغيوم، النار التي تضيء الجنة تحت أقدام الإله (100). 6- و أما الزرادشتية فهي في الحقيقة، الديانة الأولى التي أبدعت في تقديم الفلسفة الكاملة للحياة. إذ عرف مؤسسها زرادشت بكونه الفيلسوف الذي لمُيفِّق بين الديانة والحياة. فإذا أخذنا اسم الله (أهور امزدا) وحللناه فسوف نجد أن الإسم هو مركب من (أهورا) وهو أسم مذكر في الفارسية القديمة ويعني (الحياة). والاسم الثاني (مازدا)، ويعني الحكمة السامية أو العظيمة وهو أسم مؤنث. والمعنى الكامل للأسم هو (الواهب العظيم للحكمة والحياة) أو كما يترجمه معظم الباحثين (أهورامزدا ـ رب الحكمة والحياة). وهو اله واحد مطلق. وباستعحال الأسم المركب من المذكر والمؤنث معا يعني أن الله في الحقيقة هو كائن مطلق، لا يُمكن تحديد جنسه أو حصره في جنس واحد. وإكراما لهذا المفهوم لأله النور الفارسي، يُقال بأن نوعا من المصابيح سُميّت (مازدا). وأما أهريهان فهو الإله الباطل، رب الخراب والشرّ، واقف بالمرصاد لكل الأعال الخيّرة التي يقوم بها أهورامازدا. وصراعه مع الخير والنور هو صراع الموت مع الحياة. 7 - وقد حرم زرادشت عبادة الأصنام والأوثان، وقدس النار على أنها هي أصفى وأطهر العناصر المخلوقة، لا على أنها هي الخلاق المعبود، وقال: إن الخلائق العلوية كلها، كانت أرواحا صافية لا تشاب بالتجسيد، فخيرها الله بين أن يقصيها من منال أهرمن، أو يلبسها الجسد لتقدر على حربه و الصمود في ميدانه، لأن عناصر الفساد لا تحارب بغير أجساد، فأبت أن تعتصم بمعزل عن الصراع القائم بين هرمز وأخيه، واختارت التجسد لتؤدي فريضة الجهاد في ذلك الصراع. ورواية الخليقة في مذهب زرادشت، أن هرمز خلق الدنيا في ستة أدوار، فبدأ بخلق السماء ثم خلق الماء ثم خلق الأرض ثم خلق النبات ثم خلق الحيو ان ثم خلق الإنسان، وأصل الإنسان رجل يسمى كيمورث، قتل في فنتة الخير و الشر، فنبت من دمه ذكر يسمى ميشا وأنثى تسمى ميشانة، فتزاوجا وتناسلا، وساغ من أجل ذلك عند المجوس زواج 
الأخوين. قال عن الكيومثرية: انهم أثبتوا أصلين، يزدان وأهرمن، وقالوا: يزدان أزلي قديم، وأهرمن محدث خخلوق، قالوا: إن يزدان فكر في نفسه، أنه لو كان لي منازع كيف يكون، وهذه الفكرة رديئة غير مناسبة لطبيعة النور، فحدث الظلام من هذه الفكرة وسمي أهرمن، وكان مطبوعا على الشر والفتنة والفساد والضرر والإضرار، فخرج على النور وخالفه طبيعة وقولا، وجرت محاربة بين عسكر النور وعسكر الظلمة، ثم إن الملائكة توسطوا فصالحوا، على أن يكون العالم السفلي خالصا لأهرمن، وذكروا سبب حدوثه، وهؤلاء قالوا: سبعة آلاف سنة، ثم يخلي العالم ويسلمه إلى النور، والذين كانوا في الدنيا قبل الصلح، أبادهم وأهلكهم (101) الإعتقاد بالحياة الآخروية: يقول لاتنتهى حياة الإنسانية بموته في هذا العالم بل له حياة أخرى بعد هذه الحياة، فالذين عملوا الصالحات في حياتهم الدنيا يدخلون عالم السعادة والذين دنسو ا نفوسهم بالشرور يدخلون عالم الشقاء(102).

\section{المطلب السادس: الديانة الصينية:}

الصينيون يعتقدون بالإله الأعظم أو إله السماء ويتوجهون إليه بالعبادة، كما أن عبادته وتقديم القرابين إليه خصوصة بالملك، أو بأمراء المقاطعات، للأرض إله، وهو إله الأرض، ويعبده عامة الصينيين(103) تتكون عقيدة العامة لدى الصينين منذ أقدم العصور عن عبادة الأرواح الخفية والقوى الغامضة التي كانوا يشاهدون آثارها ولايدركون ماهيتها، واما الخاصة منهم فقد كانوا يقدسون السماء لما يرونه فيها من قوى كاملة لها كل سلطان على الأرض ومافيها، فهي في نظرهم الإله الأعلى (104)، يعتبر كونفوشيوس المؤسس الحقيقي لهذه العقيدة الصينية، ولد سنة (1 5 5 5) ق. م في مدينة تسو Tsou وهي إحدى مدن مقاطعة لو Lu - اسمه كونج Kung وهو اسم القبيلة التي ينتمي إليها، وفوتس Futze معناه الرئيس أو الفيلسوف، فهو بذلك رئيس كونج أو فيلسوفها، ينتسب إلى أسرة عريقة(105). ومن أهم أديان الصينية: منها الديانة الكونفوشيوسية التوحيد في الديانة الكونفوشيوسية: 
يعتقدون بالإله الأعظم أو إله السماء ويتوجهون إليه بالعبادة، كما أن عبادته وتقديم القرابين إليه غخصوصة بالملك، أو بأمر اء المقاطعات. للأرض إله، وهو إله الأرض، ويعبده عامة الصينيين (106) ولم يقل كونفوشيوس أنه نبي ولا رسول وانما كان باحثاً في الحكمة، وقد تناولت ابحاثه الحكومة والسياسة والأخلاق وكان شدد التاثير بعقائد قومه الأقدميين، فاتجه الى عدم القول بالجنة والنار والعقاب والثواب، ولم يدرس مشكلة ما بعد الموت، ولكن الصينيين من بعده انحرفوا بهه الدعوة الخيرة واتجهوا المى كونفوشيوس يبنون له الهياكل ويعبدونه، ويقدمون أمام تماثيله الذبائح والقرابين، ويركعون أمام تماثيله ويسجدون(107) الشمس والقمر، و الكواكب، والسحاب، والجبال، لكل منها إله، وعبادتها وتقديم القرابين إليها مخصوصة بالأمر اء(108) وبعد موت كونفوشيوس أقام له الصينيون معبداً وعبدوه كعادتهم في عبادة أرواح الاسلاف (109) و كونفوشيوس المى إله نظرة عدم اكتراث فهو عنده لا يتدخل بشؤون البشر (110).

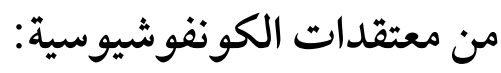

1 - عقيدة الكونفوشيوسية قائمة على عبادة السماء باعتبارها الإله الأعظم وحاكم الحكام أو رب الأرباب،

ثم عبادة الأرض لأن الأرض هي الأخرى إلهاً ن ثم عبادة أرواح الأجداد ثم عبادة الجبال والأنهار (111). 2- يعتقدون بالإله الأعظم أو إله السماء، ويتوجهون إليه بالعبادة، كما أن عبادته وتقديم القرابين إليه خصو صة بالملك، أو بأمراء المقاطعات، للأرض إله، وهو إله الأرض، ويعبده عامة الصينيين، الشمس والقمر، والكواكب، والسحاب، والجبال، لكل منها إله، وعبادتها وتقديم القرابين إليها خصوصة بالأمراء. 3- الملائكة: إنهم يقدسون الملائكة ويقدمون إليها القرابين. 4 - أرواح الأجداد: يقدس الصينيون أرواح أجدادهم الأقدمين، ويعتقدون ببقاء الأرواح، والقرابين عبارة عن موائد يدخلون بها السرور على تلك الأرواح بأنواع الموسيقى، ويوجد في كل بيت معبد لأرواح الأموات و لآلهة المنزل(112). 
5- تحترم الكونفوشيوسية العادات والتقاليد الموروثة، فهم محافظون إلى أبعد الحدود، فيقدّسون العلم والأمانة، ويحترمون المعاملة اللينة من غير خضوع ولا استجداء لجمبروت(113). - - لقد آمن كونفوشيوس بوجوب أن تعمل الحكومة على رفاهية الناس اجمعين، ورأى أن هذا لا يمكن أن يتحقق الا إذا تولى شئون الحكم أعظم الرجال كفاءة(114). 7 - عندما سئل كونفوشيوس هل على الإنسان ان يجب عدوه الذي يؤذيه ويسيء اليه؟ أجاب أبدا على الاطلاق قابل الكراهية بالعدالة والحب بالإحسان، وإلا فانك ستهدر إحسانك (115).

\section{المطلب السابع : الديانة اليابانية: الديانة الشنتوية اليابانية:}

الشنتوية ديانة وضعية إجتماعية ظهرت في اليابان منذ قرون طويلة، ولا زالت الدين الأصيل فيها، وقد بدأت بعبادة الأرواح، ثم قوى الطبيعة، ثم تطور إحترام الأجداد و الزعاء والأبطال إلى عبادة الإمبراطور الميكادو، الذي يعد من نسل الإلمة، كما يزعمون(116) لا تنتسب الشنتوية إلى شخص معين، بل هي دين اجتماعي لليابانيين (117).

\section{التوحيد في الديانة الشنتوية:}

رغم أن اليابانيين يؤمنون بآلة واحدة إلا أنهم لايقيمون لها أي وزن في تعبداتهم لأنها لا تتدخل بشؤون البشر اليومية، أما الإلهة الثانوية الأخرى كالظواهر الطبيعية والإمبراطور فإنه من الواجب القيام بالصلاة لهم و اطاعة أوامرهم المتمثلة بأوامر الامبراطور وقوانين المملكة، أن العقيدة اليابانية تتخذ وجهين: الأول: ويسمى عقيدة الدولة ويقوم اليابانيون بعبادة الحاكمين والأسلاف. والوجه الثاني: هو إتجاهـم المى عبادة أسلاف القبائل ويسمى العقيدة المنزلية، وكان كل إمبراطور حتى الحرب العالمية الثانية يعتبر ضل الله في الأرض(118). 


\section{من معتقدات الشنتوية:}

1- آمن اليابانيون القدماء بقوى الطبيعية الظاهرة لهم مثل: (الشمس، القمر، الانهار، الرعد، المطر...) ولكل منها روحاً تفيد أوتضر ولابد من عبادتها، وسموا قوى الطبيعة المهيمنة هذه باسم (كامي)، وقد اطلق الكامي على (نهر عظيم أو جبل شاهق، إنسان مهم أو إله) وكل كامي يقسم الى قسمين (إلهي وأرض) ولكل قسم روحه الخاصة به، ويعتبر الميكادو: من كون الامبراطور إلهاً على الأرض وابن الإلهة فقد عُبد تحت هذا الاسم وهو اقرب شبهاً للشمس أو للقمر (119). 2- يطلق الشنتويون لفظ كامي على كل إله أو شيء يسمو فوق الإنسان، كالسماء أو السلطان. 3 - يعد الإهتحام بالنظافة أمرا مقدسا، ويكره أتباع الشنتوية كل شيء يدنس الجسد أو الثوب. 4- ان الشنتو لم يذهبوا في معتقدهم الى الإقرار باله واحد هو الخالق الو احد للكون، وليس لعقيدة التوحيد مكان عند الشنتو، بل هم يؤمنون بتعددية الإلهة والمعبودات التي يقيمون لها المعابد الهياكل والأصنام او التماثيل، لكن (كامي) يشكل المحور في عقيدة الشنتو، والذي يشكل صورة فوق طبيعة، وان كامي عندهم له قدرات لا محدودة(120). 5 - تقوم عقيدة الشنتو على أساس تقديس الإلمة الشمس، وتقديس الامبراطور والأباطرة والافلاك تقديس الأسلاف، ولذلك يخضع له الجميع (121). 6- الكون عند الشنتويين أزلي ولا نهاية له ولا فناء للبشر فلا قيامة ولا بعث(122). 7 - وفي القرن الثامن الميلادي استطاع راهب بوذي أن يؤثر في الشنتوية على اعتبار أن آهتها مظاهر مجسدة لبوذا.

8- وفي العصر الحديث حينم) استيقظ الشعور القومي في اليابان، وبلغ ذروته في ثورة 1868م، نفر الشعب من كل ما هو أجنبي، ومنه البوذية فأزيلت تماثيل بوذا من المعابد، وأوقف الكهنة البوذيون عن ممارسة وظائنهم، وعادت الشنتوية دينا قوميا، وكانت الحكومة اليابانية تعمل على توطيد الشنتوية في البلاد للاحتفاظ بعبادة الإمبر اطور الميكادو. 
9- ولكن التسامح سائد بين البوذية اليابانية والشنتوية، وهذا نرى الناس في اليابان يتتقلون من هيكل بوذي إلى معبد شنتوي دون حرج، والعقائد التي يعتنقها الفرد الياباني العادي مزيج من الشنتوية

$$
\text { والكونفشيو سية والبوذية(123). }
$$

\section{المطلب الثامن: الديانة الصابئية:}

الديانة الصابئية: الصابئة هي طائفة الصابئة الوحيدة الباقية إلى اليوم والتي تعتبر يحيى عليه السلام نبيّّا ها، يقدّس أصحابها الكواكب والنجوم ويعظمونها، ويعتبر الاتجاه نحو نجم القطب الشمالي وكذلك التعميد في المياه الجارية من أهم معالم هذه الديانة التي يجيز أغلب فقهاء المسلمين أخذ الجزية من معتنقيها أسوة بالكتابيين

من اليهود والنصارى(124). التوحيد في الديانة الصابئية:

الصابئية ليسو ا من المنكرين لوحدانية الخالق تعالى، ولكنهم يعتقدون بأمور كخلق الخير والشر ووجود وسائط هي الكو اكب، وهذه تسيء الى عقيدتهم، وتشوش توحيدهم وإيـانهم (125) يعتقدون من حيث المبدأ بوجود الإله الخالق الواحد الأزلي الذي لا تناله الحواس، ولا يفضي إليه مخلوق. ولكنهم يجعلون بعد هذا الإله (300 ) شخصاً خلقو اليفعلو ا أفعال الإله، وهؤلاء الأشخاص ليسو آبآلة ولا ملائكة، يعملون كل شيء من رعد وبرق ومطر وشمس وليل ونهار وهؤلاء يعرفون الغيب، ولكل منهم مملكته في عالم الأنوار. هؤلاء الأشخاص الـ(360) ليسوا مخلوقين كبقية الكائنات الحية، ولكن الله ناداهم بأسمائهم، فخلقوا وتزوجوا بنساء من صنفهم، ويتناسلون بأن يلفظ أحدهم كلمة فتحمل امرأته فوراً، وتلد واحداً منهم. إن الصابئة نوعان: صابئة حنفاء، وصابئة مشركون. أما الصابئة الحنفاء: فهم بمنزلة من كان متبعا لشريعة التوراة والإنجيل قبل النسخ والتحريف والتبديل من اليهود و النصارى، وهؤ لاء حمدهم الله وأثنى عليهم. والثابت أن الصابئين قوم ليس لهم شريعة مأخوذة عن نبي، وهم قوم من المجوس واليهود والنصارى ليس لهم دين، ولكنهم عرفوا الله وحده، ولم يحدثو اكفرا، وهم متمسكون (بالإسلام المشترك) وهو عبادة الله وحده، وإيباب الصدق والعدل، وتحريم الفواحش والظلم 
ونحو ذلك مما إتفقت الرسل على إيجابه وتحريمه، وهم يقولون (لا إله إلا الله). فقط، وليس لهم كتاب ولا نبي. والصحيح أنهم كانوا موجودين قبل إبراهيم عليه الصلاة والسلام بأرض اليمن. وأما الصابئة المشركون: فهم قوم يعبدون الملائكة، ويقرؤون الزبور ويصلون، فهم يعبدون الروحانيات العلوية(126)، واطلق المؤرخون المسلمون أسم الصابئة على الطائفتين: الحرانية والمندائية، وكل ما قالوه إن الصابئة قسمان: أحدهما القائلون باهياكل وهم عبدة النجوم. والآخرون القائلون بالأشخاص وهم عبدة الأصنام. ان الحرانية: هم المعروفون بالصابئة وكانو ا يسكنون مدينة حران ويتخذون أصناما على مثال الهياكل السبعة. وأن الصابئة المندائية: قوم موحدون لله وكا كانوا خليطاً من الآراميين والفرس كذلك ديانتهم مزيجا من الفكرين اليهودي والمانوي(127). من معتقدات الصابئية: 1 - يعتقدون بأن الكواكب مسكن للملائكة، ولذلك يعظمونها ويقدسونها، يقول الامام القرطبي: الصابئين قوم يعبدون النجوم. 2- الصابئة المعاصرون عندهم كتب يسمونها مقدسة منها كتاب (كنزربا) بالعودة المى نصوص هذا الكتاب يلاحظ ان الصابئة موحدون، وأنهم ينزهون الله كتنزيه المؤمنين، في نصوصهم يظهر الصابئة مؤمنين بو حدانية الله وينزهونه عن الشبيه والتجسيم مع اقرار بقدرته وسائر صفاته وانعمه على المخلوقات، مع هذا يقولون بتعظيم الكواكب والبروج، ويصورونها في هياكلهم ويقولون بقدمها، ويقربون الذبائح، ولهم صلوات خمس في اليوم والليلة تقرب من صلوات المسلمين، ويصومون شهر رمضان، ويستقبلون في صلاتهم الكعبة والبيت الحرام (128). 3- المندي: هو معبد الصابئة، وفيه كتبهم المقدسة، ويجري فيه تعميد رجال الدين، يقام على الضفاف اليمنى من الأنهر الجارية، له باب واحد يقابل الجنوب بحيث يستقبل الداخل إليه نجم القطب الشمالي، 
لابدَّ من وجود قناة فيه متصلة بجاء النهر، ولا ييجوز دخوله من قبل النساء، ولا بدّ من وجود علم يميى

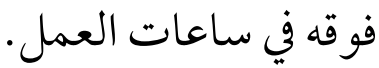
4- الطهارة: الطهارة مفروضة على الذكر والأنثى سواء بلا تمييز، تكون الطهارة في الماء الحي غير المنقطع عن مجر اه الطبيعي (129). 5- تعتقد الصابئة في الله عز وجل أنه علة الكائنات والو جود، حي بنفسه أزلي أبدي. 6- يعتقدون أن الموت انتقال من العالم المادي الذي هو بمثابة سجن ومنفى مؤقت للروح التي سرعان ما تحرر بالموت(130). 7 - يتنبئون بحوادث المستقبل عن طريق التأمل في السماء و النجو موبعض الحسابات الفلكية. 8 - يؤمنون بالتناسخ ويعتقدون بتطبيقاته في بعض جو انب عقيدتهم (131). 9 - أهه ينزهون الله كتنزيه المؤمنين، في نصوصهم يظهر الصابئة مؤمنين بوحدانية الله وينزهونه عن الشبيه والتجسيم مع إقرار بقدرته وسائر صفاته وانعمه على المخلوقات.

\section{المطلب التاسع : الديانة اليزيدية:}

اليزيدية: فرقة منحرفة نشأت سنة 132 هـ إثر انهيار الدولة الأموية، كانت في بدايتها حركة سياسية لإعادة بجد بني أمية ولكن الظروف البيئية وعوامل الجهال إنحرفت بها فأوصلتها إلى تقديس يزيد بن معاوية وإبليس الذي يطلقون علية اسم (طاووس ملك) وعزازيل (132). التوحيد في الديانة اليزيدية: - مئ

الشهادة: أشهد واحد الله، سلطان يزيد حبيب الله (133) الشيخ آدي والذي عرف بعدي بن مسافر الاموي: هو رمز اله المطر والخير والبركة(134). التوحيد فكرة ضبابية قلقة عند اليزيدية لآنها خليط من الإعتقاد الصوفي الحلولي السياسي بجانب تقديس أشخاص لحد الألوهية مثل الشيخ عدي بن مسافر ويزيد بن معاوية الذي ينسبون اليه. ويعتقدون أن الله عز وجل هو الخالق وأنه خلق ما في السماوات والأرض، ثم خلق سبعة آلهة وأن ليس هؤلاء الإلهة المتسلط هو 
طاووس ملك. ثم ربطوا هؤلاء الإلهة بشيوخ الطريقة العدوية على أساس الإتحاد والحلول على الأكثر، أي أن هذه الإلهة حلت بهؤلاء الشيوخ (135) يقدسون إبليس، وترجع فلسفة هذا التقديس لديهم إلى أمور هي: أ- لأنه لم يسجد لآدم فإنه بذلك، في نظرهم ـ يعتبر الموحد الأول الذي لم ينس وصية الرب بعدم السجود لغيره في حين نسيها الملائكة فسجدوا، إن أمر السجود لآدم كان مجرد اختبار، وقد نجح إبليس في هذا الاختبار فهو بذلك أول الموحدين، وقد كافأه الله على ذلك بأن جعله طاووس الملائكة، ورئيساً عليهم. ب-- ويقدسونه كذلك خوفاً منه لأنه قوي إلى درجة أنه تصدى للإله وتجر أ على رفض أوامره. ت- ويقدسونه كذلك تمجيداً لبطولته في العصيان و التمرد. ث - أغوى إبليس آدم بأن يأكل من الشجرة المحرمة فانتفخت بطنه فأخر جه الله من الجنة. ج- إن إبليس لم يطرد من الجنة، بل إنه نزل من أجل رعاية الطائفة اليزيدية على وجه الأرض، جرَّهم إعتبار إبليس طاووس الملائكة إلى تقديس تمثال طاووس من النحاس على شكل ديك بحجم الكفِّ المضمو مة وهم يطوفون بهذا التمثال على القرى لجمع الأمو ال(136). ح- وفي معتقدهم أنه في آخر الزمان سيصلح علاقته مع الخالق، وبعدها يستعيد مكانته التي كان فيها قبل الطرد من الجنة. خ- الشيطان عند اليزيدية يسمي: طاوس ملك(137) وفي طقوسهم يستخدمون طاووساً من المعدن، وملة عزر ائيل أعنى طاوس ملك، وهي ملة يزيدية(138)، إتصل عدي بن مسافر بالشيخ عبد القادر الجيلاني المتصوف، وقالوا بالحلول والتناسخ ووحدة الوجود. وهم يؤمنون بوجود اله أكبر خالق لهذا الكون، الا أنه الآن لا يعني بشئونه بعد أن فوض أمر تدبيره وارادته الى مساعده ومنفذ مشيئته (ملك طاووس) الذي يرتفع في أذهان اليزيدية الى مرتبة الألوهية(139). من معتقدات الديانة اليزيدية: 1 - جرَّهم اعتبار إبليس طاووس الملائكة إلى تقديس تمثال طاووس من النحاس على شكل ديك بحجم الكفِّ المضمو مة وهم يطوفون بهذا التمثال على القرى لجمع الأموال. 
2- وقفوا أمام مشكلة لعن إبليس في القرآن فاستنكروا ذلك أيضاً وعكفوا على كتاب الله يطمسون بالشمع

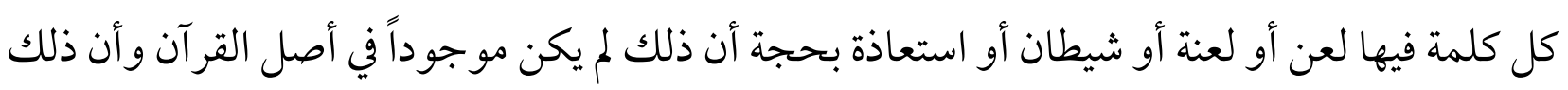

$$
\text { زيادة من صنع المسلمين. }
$$

3- وفي معتقدهم أنه في آخر الزمان سيصلح علاقته مع الخالق، وبعدها يستعيد مكانته التي كان فيها قبل

$$
\text { الطردمن الجنة. }
$$

4- - واليزيديون الذين يهملون عبادة الخالق سبحانه ويركزون على تقديس طاووس ملك، يبررون فعلهم بان

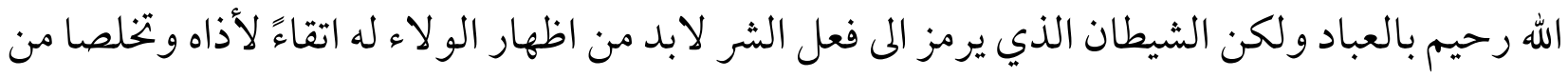

$$
\text { شره (140) }
$$

5- ان اليزيديين يرفضون الجمع بين حرفي الشين والطاء ويحر مون البصاق على الأرض، وأنهم يتشائمون من أي لعن، ويقولون (ان الملك رفض السجود لآدم هو احد الملائكة السبعة لديهم وهو عزرائيل)(141) ومعروف بطاووس ملك، و تقديراً لهذا الرفض انعم الله عليهم نصب رئيس الملائكة (142).

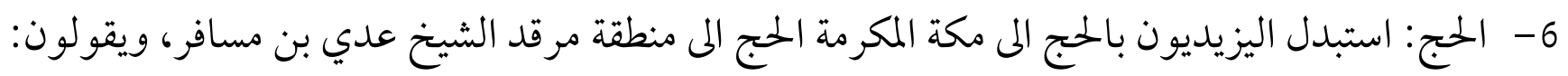
(ان جبل لالش مثل مكة التي يهج اليها المسلمون، والكعبة عندهم مرقد الشيخ عدي وجبل لالش هو

$$
\text { جبل عرفات، ونبع الماء الذي يخرج من جبل لالش هو نبع زمزم) (143). }
$$

7 7- ويزعم اليزيديون ان عدي بن مسافر قد اسقط عنهم العبادات التي يؤديها المسلمون، وقام باختصار

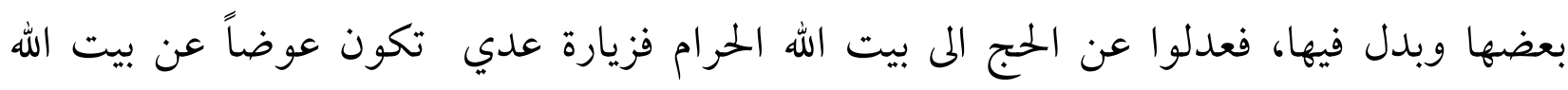

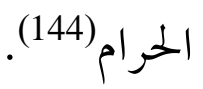

8 - يترددون على المر اقد والأضرحة كمرقد الشيخ عدي بن مسافر، وعبد القادر الجيلاني (145). 


\section{المطلب العـاشر: الديـانة البـابيـة}

مؤسس البابية هو علي محمد الشيرازي من مواليد شيراز 1819 م، زعم الشيرازى أنه الباب للقرن التاسع

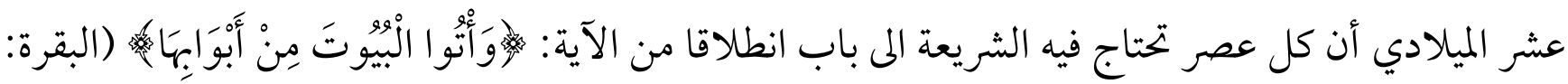
189 1 ) وحديث: (أنا مدينة العلم وعلي بابها)(146) وبذلك اطلق على نفسه اسم الباب ودعوته عرفت بالبابية. التوحيد في الديانة البابية:

كان الإعتقاد بوجود اله واحد أزلي تستمد صفاته من أساس العقيدة الباطنية، ومن الناحية الإعتقادية يبنون كل مظاهر العمل والعبادة على أنها أمور ظاهرية تعبر عن أمر باطني، فيقول الباب: إن الحقيقة الروحانية المنبعثة من الله، قد حلت في شخص الباب حلو لاً مادياً جسمانياً، وأن الأنبياء جميعاً من لدن آدم قد تجسدوا في شخصه، واتخذوا منه سبيلاً للعودة المى الدنيا من جديد، وكان يرى الباب نفسه الممثل الحقيقي لهؤلاء الأنبياء والمعبر عن رسالتهم (147) إدعى أن الإله حلّ به، وكان أتباعه ينادونه بالرب وبالإله (148) يعتقد الباب في أن أرفع مراتب الحقيقة الإلهية حلت في شخصية حلولاً مادياً وجسمياً(149) وللبابية تعاليم تتناول العقائد والعبادات خرجوا فيها على الإسلام، وخالفوا ما جاء في الكتاب و السنة، فهم يرون أن الله يحل فى البشر، وأن حلوله فى بشر يعتبر مظهر ا إلهيا فى هيكل بشرى، وهذا كفر صُراح، وأنحا ظهور الله فى هيكل تعدد بتعدد الأنبياء و الرسل، وأن الظهور الأخير أتم من الظهور الأول، ومن هنا يعتبر الباب نفسه أكمل مظهر بشرى للحقيقة الإلهية وهم يكفرون بالآخرة(150) يعتقدون أن الله تعالى ليس خالق كل شيء بل يخلق المشيئة الإلهية التي تظهر في مظاهر الله (151).

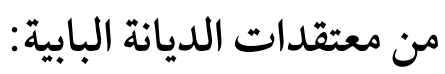
1 - يعتقد الباب في أن أرفع مراتب الحقيقة الإلهية حلت في شخصية حلو لاً مادياً وجسمياً(152). 2- وللبابية تعاليم تتناول العقائد والعبادات خرجوا فيها على الإسلام، وخالفو ا ما جاء فى الكتاب والسنة، فهم يرون أن الله يحل فى البشر، وأن حلوله فى بشر يعتبر مظهرا إلهيا فى هيكل بشرى. وهذا كفر صُراح، 
و أنحا ظهور الله فيكل تعدد بتعدد الأنبياء والرسل، وأن الظهور الأخير أتم من الظهور الأول، ومن هنا يعتبر الباب نفسه أكمل مظهر بشرى للحقيقة الإلهية وهم يكفرون بالآخرة(153).

3 - يعتقدون أن الله تعالى ليس خالق كل شيء بل يخلق المشيئة الإهية التي تظهر في مظاهر الله (154). 4- وزعم انه المهدي وان جسم المهدي اللطيف قد حل في جسمه المادي، وانه ظهر الآن في هذا العالم ليمحوَ الظلم وينشر العدل.

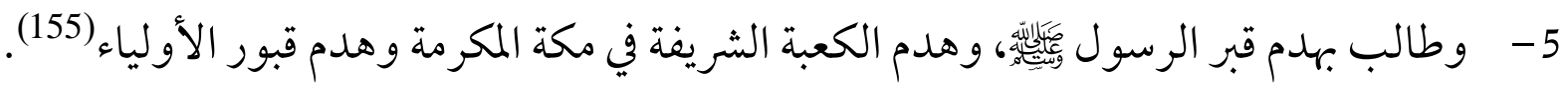
6- الربا في الديانة البابية والبهائية جائزة فقد إعتبره جائزاً في المعاملات كح) قال الباب: (أذن الله للتجار في البيع والشراء إذا تحقق الرضا بينها بأي نحو كان)(156). 7 - إفترى الباب على الله كذبا أنه جاء لينسخ شريعة الإسلام ولهذا عمل على أن يكون لأتباعه عباداتهم الخاصة التي تختلف عن عبادات المسلمين في الصلاة والصوم والزكاة والحج والاحوال الشخصية(157). 8 - والبابية تقول بقدسية العدد تسعة عشر، وهو نفسه عدد حروف بسم الله الرحمن الرحيم كما كتب، والسنة البهائية تسعة عشر شهراً، والشهر تسعة عشر يوما(158).

\section{المطلب الحادي عشر: الديانة البهائية:}

مؤسس البهائية حسين على نوري بن بزرك المازندراني ولد 1817 م وكان شقيقه يحيى من أركان البابية وقد بدأ ينشط للبروز بين البابيين بعد اعدام الباب، اعلن دعوته عام 1863م في بغداد وزعم المازندراني انه المقصود بدعوة (البيان) التي جاء بها على محمد الشيرازي (الباب) وانه قد حلت فيه بعض الوهية(159). البابية والبهائية حركة نبعت من المذهب الشيعي الشيخي (160) تحت رعاية الاستعحار الروسي واليهودية العالمية والإستعهار الإنجليزي بهدف إفساد العقيدة الإسلامية وتفكيك وحدة المسلمين وصرفهم عن قضاياهم الأساسية(161). 


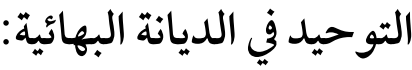

الباب هو الذي خلق كل شيء بكلمته وهو المبدأ الذي ظهرت عنه جمع الأشياء، وان أرفع مراتب الحقيقة الإلهية حلت في شخصية البهائية حلو لا ماديا وجسميا(162) افترى الباب على الله كذبا انه جاء لينسخ شريعة الإسلام ولهذا عمل على ان يكون لأتباعه عباداتهم الخاصة التي تختلف عن عبادات المسلمين في الصلاة و الصوم والزكاة والحج والأحوال الشخصية والميراث(163)، البهائيين يعتقدون في اله واحد، لا يفنى، خالق كل شيء، بها في ذلك جميع المخلوقات والقوى في الكون، في الإيحان البهائي، يتخطى الله المكان والزمان، ولكن يُو صف أيضًا بأنه "إله شخصي، لا سبيل إلى إدر اكه، يتعذر الوصول إليه، مصدر كل رؤيا، أبدي، كلي العلم، منتشر في كل مكان وقدير. على الرغم من عدم إمكانية الوصول إليه مباشرة، إلا أن الله ينظر إليه على أنه واعٍ للخلق، يمتلك عقلاً وإر ادة وغرضًا. يعرض البهائيون تصوراً للألوهية يؤدي في النتيجة الى تأليه الباب وبهاء الله، وتأليه ذلك الذي سيظهر في وقت المنتهى ليكون ملك العالم(164) يرى لبهائيون أن التوحيد هو معرفة الأجساد البشرية التي حلت أو تجلت فيها حقيقة الإلهية، فكل ما يقال عن الله يجب أن يقال عن الجسد البشري الذي حلت فيه الألوهية وهو البهاء، فهم يؤلهونه، ويعبدونه، ويزعمو أنه لايعزب عن علمه شيء(165) يقولون: (إن الله تعالى لايوصف بوصف ولايسمي باسم فهم بذلك ينظرون الى الله أنه عدم ومن عقائدهم وجوب عدم المواظبة على الصلاة وعدم الانتظام فيها صفوفاً وقبلتهم ليس الكعبة)(166) البهائية يؤمنون بإله ليس له وجود مطلق وإنحا وجوده مفتقر إلي خلقه فهو مفتقر إلى من يظهر من خلاله وهؤلاء هم الأنبياء و الرسل فيتجلى لعباده من خلالهم بعدما يحل بهم حتى يتحد معهم فيصير الله والرسول شيئا واحدا تعالى الله عا يقولون علو اكبير (167)

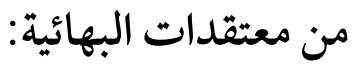

1 - يقولون بالحلول والاتحاد والتناسخ وخلود الكائنات وان الثواب والعقاب إنها يكونان للأرواح فقط

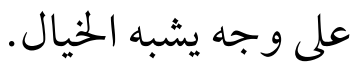
2- - ينكرون معجزات الأنبياء وحقيقة الملائكة والجمن كما ينكرون الجنة والنار. 


$$
\text { - } 3 \text { - يجرمون الحجاب على المرأة ويحللون المتعة وشيوعية النساء والأموال. }
$$

5 - يؤولون القيامة بظهور البهاء، أما قبلتهم فهي إلى البهجة بعكا بفلسطين بدلاً من المسجد الحرام. - - ينكرون أن محمداً - خاتم النبين مدعين استمرار الوحي وقد وضعوا كتباً معارضة للقر آن الكريم مليئة بالأخطاء اللغوية والركاكة في الأسلوب(168). 7 - النار والقيامة والبعث والنشور والحساب وكل مسائل السمعيات التي يؤمن بها اتباع الشرائع الثلاثن يؤولون كل هذه السمعيات تأويلا خاصا يتفق مع عقائدهم (169). - - أن البهائية فرقة باطنية، وأنهم يقولمن بالتأويل الباطني ونحو ذلك مما تقول به الباطنية(170). 9- كذلك ينكر البهائيون الملائكة فيجعلو نهم المؤمنين بعقيدتهم ويجعلون الشياطين هم أهل بقية الملل (171). 10 - إذا الشمس كورت: أي انتهت الشريعة المحمدية وجاءت الشريعة البهائية(172).

\section{المطلب الثاني عشر: الديـانة القاديانية:}

القاديانية حركة نشأت سنة 1900 م بتخطيط من الاستعمار الإنجليزي في القارة الهندية، بهدف إبعاد المسلمين عن دينهم وعن فريضة الجهاد بشكل خاص، حتى لا يو اجهو ا المستعمر باسم الإسلام، وكان لسان حال هذه الحركة هو مجلة الأديان التي تصدر باللغة الإنجليزية(173) مؤسسها الميرزا غلام أحمد القادياني - نسبة إلى بلدة قاديان، مات سنة 1908م، صوفي أخبره الكشف أنه مكلف من الله تعالى بإصلاح الخلق على نهج المسيح عيسى ابن مريم عليه السلام، وقد صرح أن له إلهام ومكاشفات. التوحيد في الديانة القاديانية: ومن مكاشفاته: روح المسيح حلت فيه، ما يلهمه هو كلام الله كالقرآن الكريم والتوراة والإنجيل، المسيح (الذي هو هو) سينزل في قاديان، قاديان هي البلدة المقدسة الثالثة المكنى عنها في القرآن بالمسجد الأقصى، الحج إليها فريضة، أوحي إليه بآيات تربو على عشرة آلاف آية، القرآن ومحمد وسائر الأنبياء قبله قد شهدوا له بالنبوة وعينو ازمن بعثنه ومكانها. اهـ. - مه. 
ومن أقواله: إن الله يكلمني كما يكلم المحدثين... جاء جبريل واصطفاني وأدار إصبعه وأشار أن ربك سيعصمك من الأعداء... ومن أقواله: لقد حرم الذين سبقوني من الأولياء والأبدال والأقطاب من هذه الأمة المحمدية من النصيب الأكبر من هذه النعمة (المكالمة الإلهية)، ولذلك خصني الله باسم (النبي)، أما الآخرون فلا يستحقون هذا الاسم، نرى الميرزا نفسه يعترف بأنه من الأقطاب، وأنه محدث، وأنه مكاشف، وأنه من بين الذين سبقوه من الأولياء والأبدال والأقطاب هو الوحيد الذي خصه الله بالنبوة. أي: إن الصوفية هي وراء القاديانية، وطبعاً هناك خلفيات ليس هنا بجال بحثها، لكن لا بأس من التذكر هنا أن الصوفية اليهودية هي

$$
\begin{aligned}
& \text { التي تسمي الو اصل فيها (نبياً)(174). } \\
& \text { من معتقدات القاديانية: }
\end{aligned}
$$

1 - ويعتقدون بالتناسخ و الحلول، وان إلههم له صفات البشر فهو يصلي ويصوم وينام ويخطىء(175). 2- موقف الإسلامي من القاديانية: تحكم بالردة على من اتبع القاديانية و يعد خارجا عن ملة الإسلام،

وجاء القاديانية خارجة عن الإسلام خروجاً كاملاً، وأن معتنقيها كفار مرتدون عن الإسلام (176).

- - نستطيع أن نفر لتصوير وجود الله بأن له أيادي وأرجلاً كثيرة وأعضائه بكثرة لا تعدو و لاتحصى (177). 4 - يعتقد القاديانيون أن الله يصوم ويصلي وينام ويصحو ويكتب ويخطئ ويجامع ـ تعالى الله عما يقولون

$$
\text { علوَّا كبيراً. }
$$

- - يعتقد القادياني بأن إلهه إنجليزي لأنه يخاطبه بالإنجليزية.

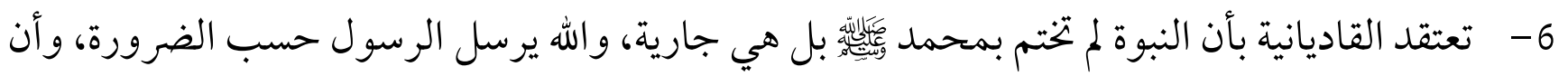
غلام أحمد هو أفضل الأنبياء جميعاً.

7 - يعتقدون أن جبريل عليه السلام كان ينزل على غلام أحمد وأنه كان يوحى إليه، وأن إلهاماته كالقرآن. 8 - يقولون لا قرآن إلا الذي قدمه المسيح الموعود (الغلام)، ولا حديث إلا ما يكون في ضوء تعليم|ته، ولا نبي إلا تحت سيادة غلام أحمد. 
9 - نادو ابإلغاء عقيدة الجهاد كما طالبو ابالطاعة العمياء للحكومة الإنجليزية لأنها حسب زعمهم ولي الأمر

$$
\text { بنص القرآن. }
$$

10 - كل مسلم عندهم كافر حتى يدخل القاديانية: كما أن من تزوج أو زوج من غير القاديانيين فهو كافر. 11 - يؤمنون بأن الحج المفروض هو الحضور في المؤتمر السنوي في القاديان(178). 12 - يعتقد القادياني بأن الهه إنجليزي لأنه يخاطبه بالإنجليزية وتشبيهه الله تعالى بالبشر !(179). 13 - حدد في خطبه له أنه الإله وان إيحاءاته معصومة من الخطأ(180).

- التوحيد يعني الإيحان بأنه لا إله إلا الله. أي لا خالق إلا الله، ولا كامل إلا الله؛ فهو القادر المالك والذي بيده كل شي، و إثبات كل صفة كحال لله سبحانه وتعالى، ونفي كل صفة نقص عنه عز وجل. - - العقيدة الصحيحة هي التي فطر الله تعالى عليها جميع الخلق اذن هي العقيدة الفطرية التي تتفق مع العقل ولا تناقض بها. - ميأتي على عكس التوحيد الشرك، وهو الاعتقاد بكل ما يضاد التوحيد. ومن الشرك اعتقاد وجود خالقين للكون والحياة والإنسان، ومنه اعتقاد أن غير الله الخالق يستحق العبادة، ومن الشرك اعتقاد أن شيئا من الطاعة يو جه إلى غير الله، ومنه اعتقاد وجود شبيه أو كفؤ لله، و منه اعتقاد أن الله يتصف بضعف، أو بشيء مما هو من صفات النقص، وهكذا. - علم التوحيد هو أصل العلوم الإسلامية وأفضلها وأهمها على الاطلاق، وأشرف العلوم الدنيوية والدينية. - ان الانحر اف بالأديان هو الذي سبب الصراع بين معتنقها، ولو سارت الأديان سيرها الطبيعي كرسالات من عند الله دون تحريف لالتقت جميعا في اهدافها جميعا في اهدافها وفي كثير من وسائلها، والإسلام الدين الوحيد الذي سلم كتابه من التحريف والتبديل. 
- عرف الهنود بكثرة آلهتهم وتعدد ديانتهم، وقد كان من أبرز معتقداتهم الايحان بالثالوث، وكذلك جميع

$$
\text { الأديان الوضعية والمنحرفة. }
$$

- - أن جهود الإنحراف التهت بكل قواها وشرورها الى الله سبحانه وتعالى منها: اتجاه التعدد في الهندوسية وتأليه البقرة، ويرى كذلك تأليه جينا، وتأليه بوذا، وتأليه العجل، وتأليه المسيح، وقد اتجهت المحاولة كذلك للاسلام، فنجا الإسلام وحده من محاولات التحريف في عقيدة الألوهية. - - إن القرآن الكريم بيّن حقيقة عيسى عليه السلام وكونه لا يعدو الا ان يكون عبداً ورسولاً لله تعالى من أولى العزم.

- - وأرسل الله تعالى المسيح ويدعوا بني اسرائيل الى اعتناق هذا الدين المؤسس على الاعتراف بالخالق ووحدانيته.

- لقد ذكر الله سبحانه وتعالى أن أخبار اليهود قد قاموا بتحريف التوراة، وانهم اضافوا اليهان وأنقضوا منها، ولايعترف القرآن الكريم بالتوراة المحرفة التي وصاغها احبار اليهود. - ـ ولقد كان لليهود أثر بارز في انحراف النصرانية عن التوحيد، ووصولها المى ما آلت اليه من انحراف في عقيدتها، ومما لا شك فيه ان اليهود وهم الشعب الذي تتجلى فيه الأنانية دائماً يكرهون كل ما سواهم، وموقفهم من انبيائهم ذكره القرآن الكريم.

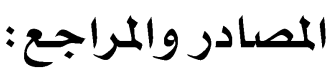

1. ابراهيم: ابراهيم محمد ابراهيم، الأديان الوضعية في مصادرها المقدسة، ط1، مطبعة الامانة، 1985، مصر .

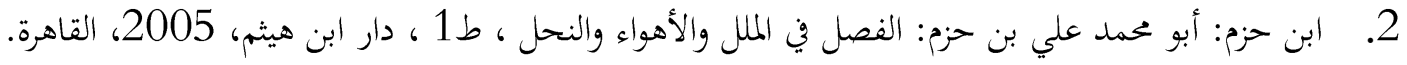

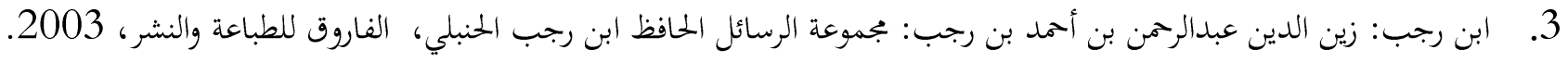

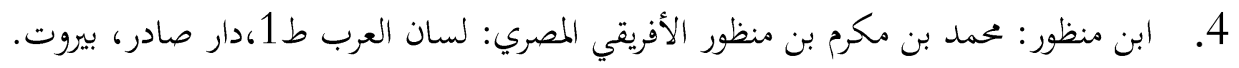

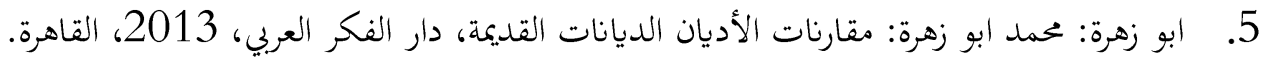

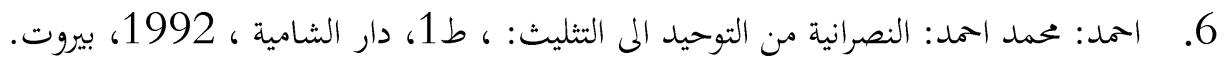

7. 
8. الأمين: عبد الله الامين: دراسات في الفرق والمذاهب القديمة والمعاصرة ، ط2، دار الحقيقة، 1991 بيروت.

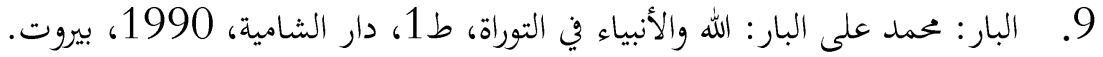

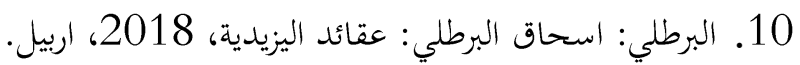

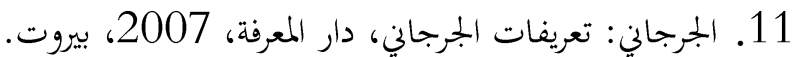

12. الجزائري: ابوبكر الجزائري: عقيدة المؤمن، مكتبة الايمان، القاهرة.

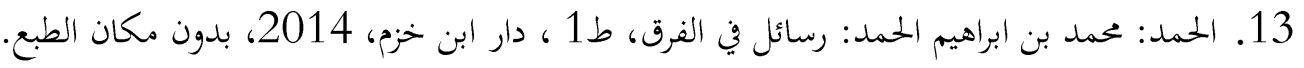

14. الخطيب: مصطفى عبدالكريم الخطيب: معجم المصطلحات والالقاب التأريخية.

15. الحخيون: رشيد الخيون: الأديان والمذاهب بالعراق: ، ط1، 1426 14هـ، بغداد.

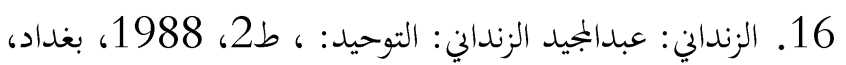

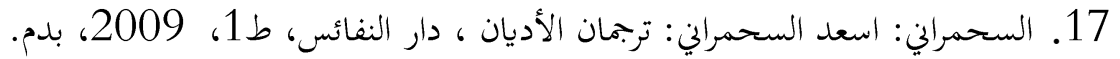

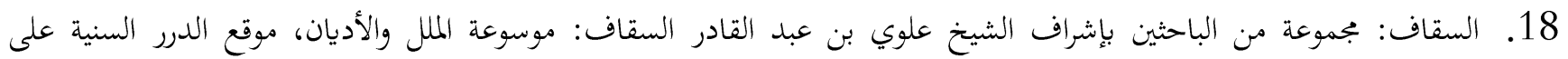

الإنترنت، 1433هـ.

19. السكندري: أبوحفص عبد السلام السكندري: فنتة البهائية تاريخهم عقائدهم حكم الإسلام فيهم ، موقع صيد الخاطر.

20. السيد: خالد كمال السيد: الديانة البوذية ،، 2010، 2010، دار حوران، دمشق.

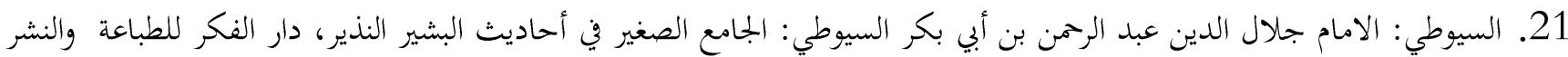

والتوزيع، بيروت.

22. الشريف: محمود بن الشريف: الأديان في القرآن: ، ط4، دار المعارف، 1980، مصر.

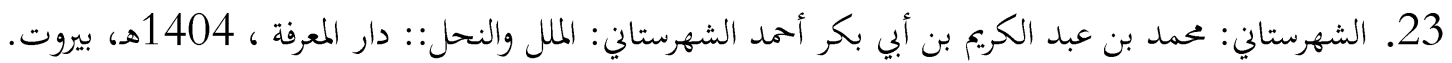

24. الطبراني: الامام البراني: المعجم الكبير .

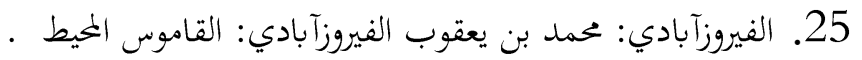

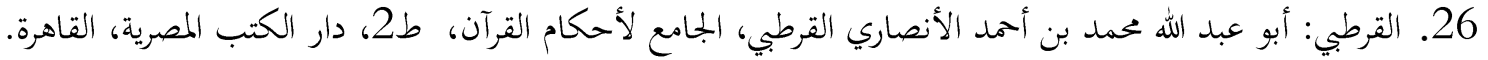

27. القيسي: مروان إبراهيم القيسي: معالم التوحيد ، ط2، المكتب الإسلامي، ، 2012، 2012، بيروت.

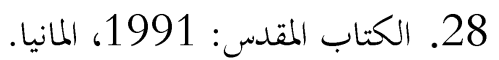

29. المارديني: عبد الرحيم المارديني: موسوعة الأديان الحية في العالم ، دار الاية، 2009، دمشق.

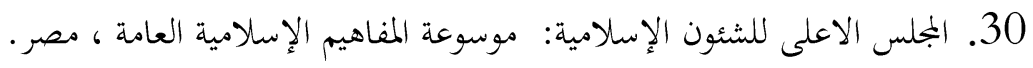

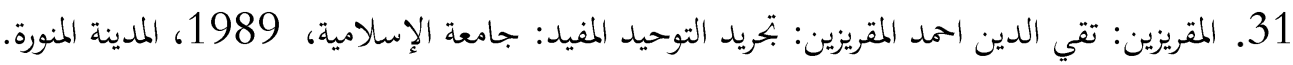

32. النجار: عامر النجار: البهائية وجذورها البابية، ط1، 1996، 193، القاهرة.

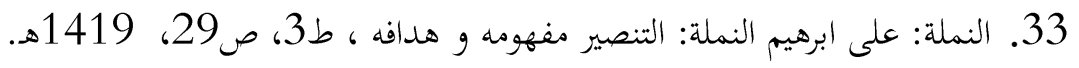

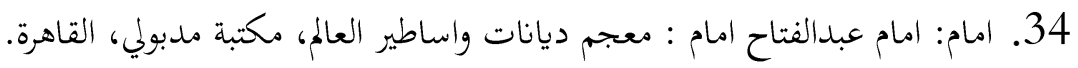

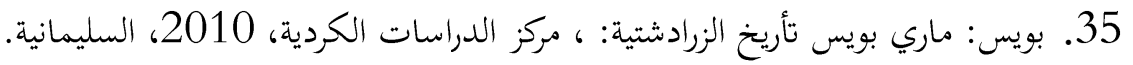


36. تونسي: محمد خليفة التونسي، البروتوكولات حكماء صهيون: ، ط1، مطبعة ياسين، 2005.

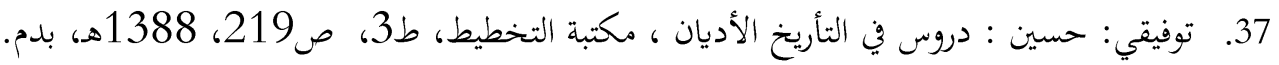

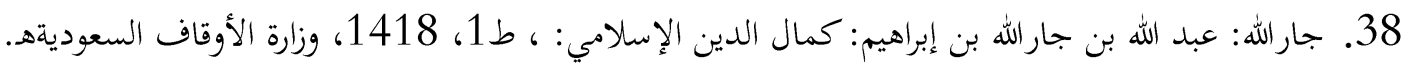

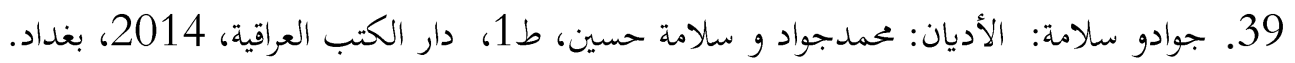

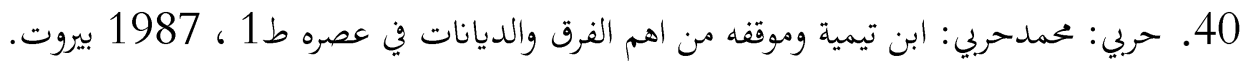
41. حسان: محمد حسان: حقيقة التوحيد ، مكتبة فياض ، 2007، 2007، القاهرة.

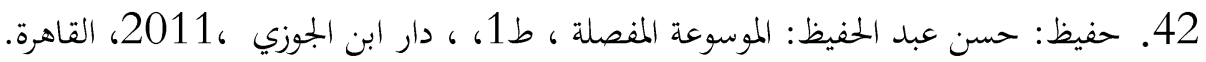

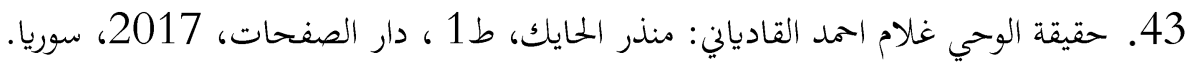

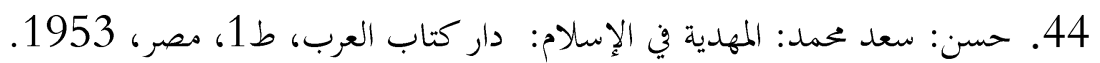

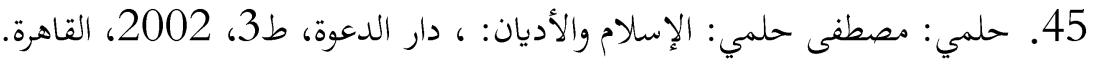

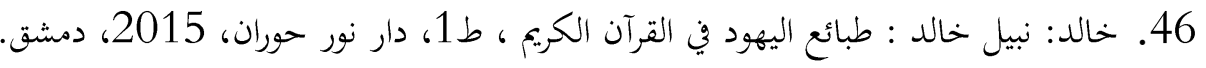
47. الخطيب : مصطفى عبدالكريم :معجم المصطلحات والالقاب التأريخية، مؤسسة الرسالة، بيروت. 48. ديدات: احمد: الله في اليهودية والمسيحية والإسلام: مكتبة الديدات، القاهرة، 1990. 49. دربالة: اسلام محمود دربالة موسوعة، الفرق والأديان: ط1 ، مكتبة الإيمان، 2007 ، القالان القاهرة.

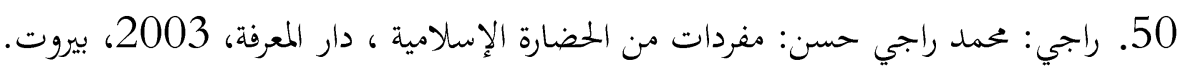

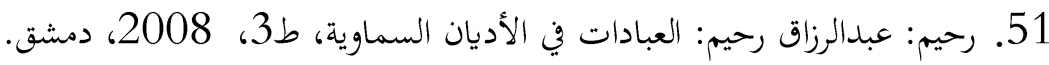
52. زهران: البهائية: طلعت زهران، الاسكندرية بدون الطبع والسنة.

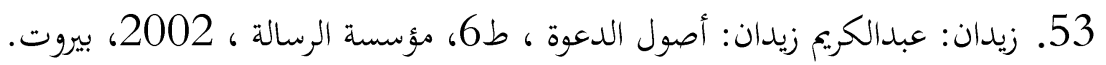
54. زينو: محمد جميل زينو: ختصر العقيدة الإسلامية، بدوم سنة.

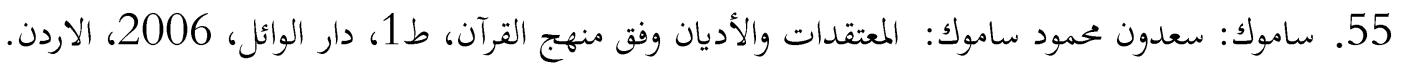

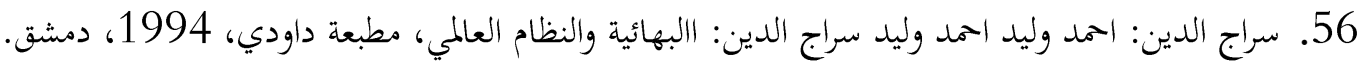
57. سعيد: أديان العالم: حبيب سعيد، دار للكنيسة الاسقفية، القاهرة. 58. سميث: أديان العالم: هوستن سميث، ط3، دار الجسور للثقافة، 2007، حلب.

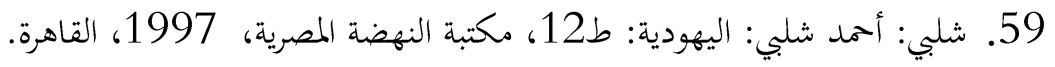

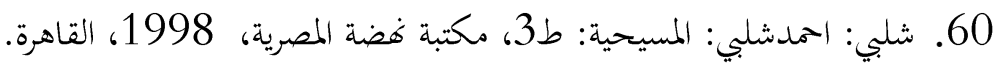

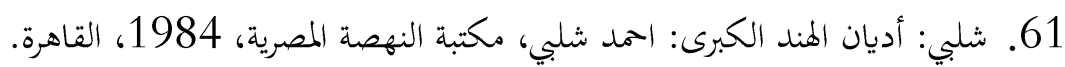

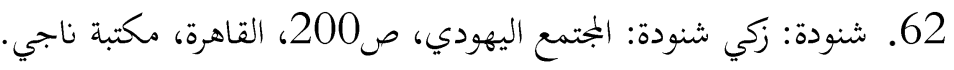

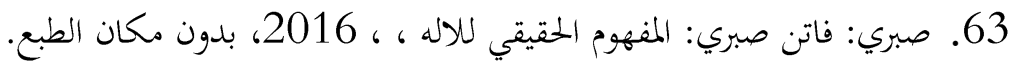

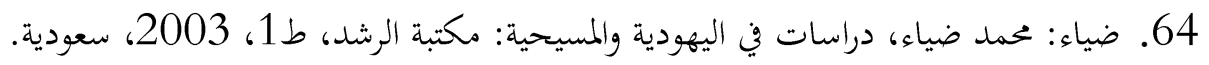

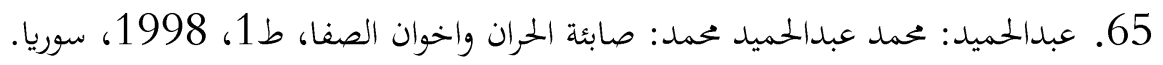


66. عبدالعزيز : سعود بن عبدالعزيز: دراسات في الأديان اليهودية والنصرانية، ط1، 1997، المدينة المنورة.

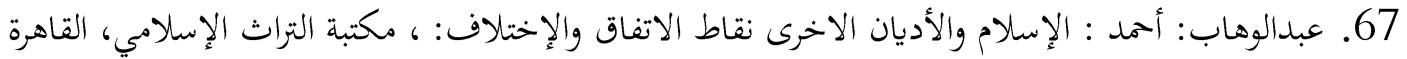

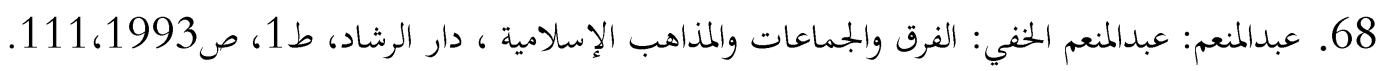

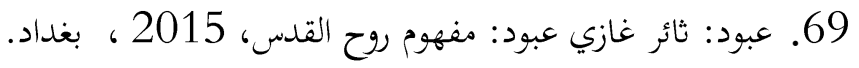

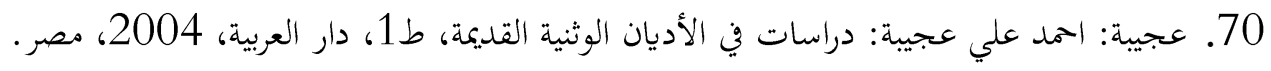

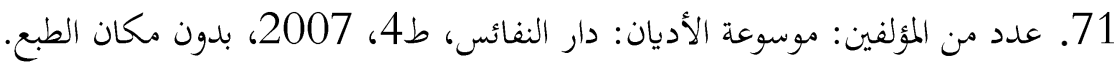

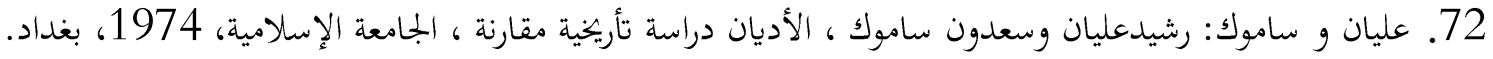

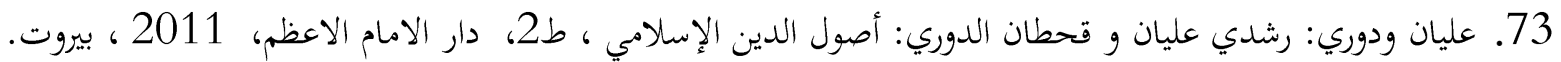

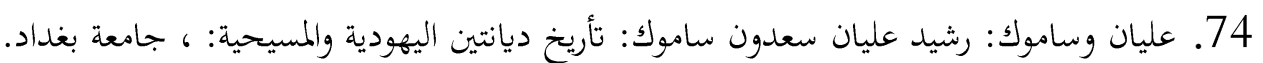
75. عمار: المدعمار: اليهود أخلاقهم وشريعتهم ، ، دار نورحوران، 2019 ، دمشقان. 76. عويس: عبدالحليم عويس: موسوعة مصطلحات علوم القرآن، ط1 ، دار الوفاء ، 2007، 2007، مصرد.

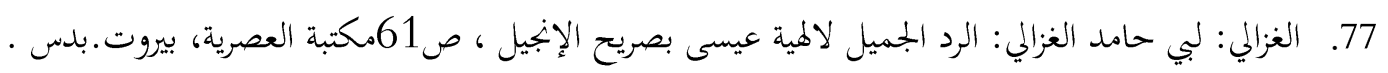

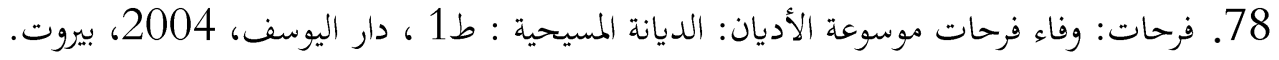

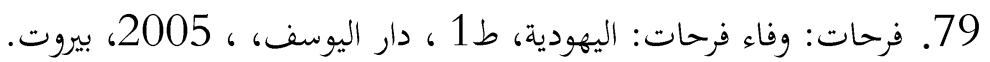
80. قطب: محمد قطب: مذاهب فكرية معاصرة: ، دار الشروق ، 2008، القاهرة.

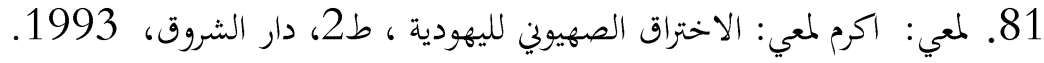

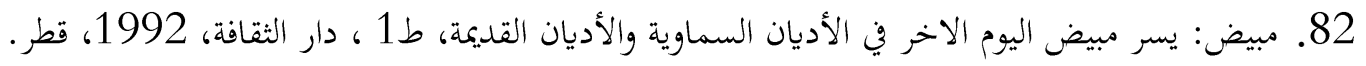

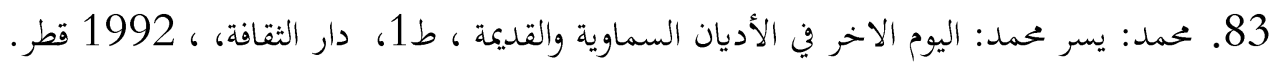

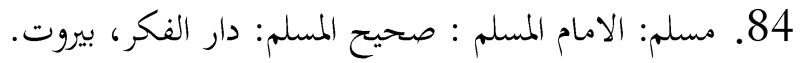
85. مجموعة من المؤلفين: المعجم الوسيط، دار الدعوة، بدس.

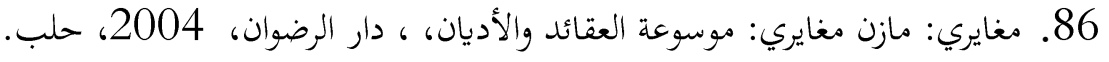

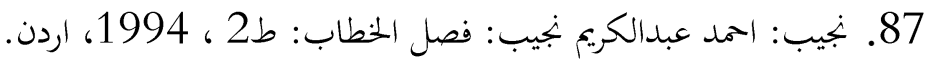

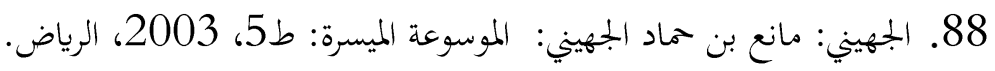

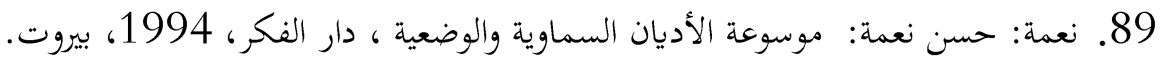

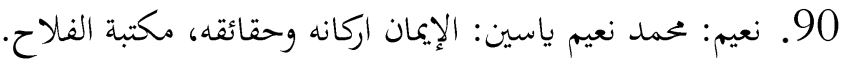

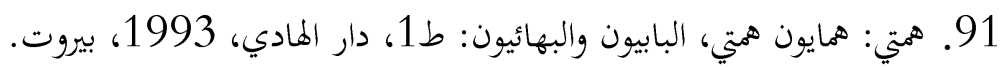




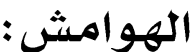

(1) حلمي: مصطفى: الإسلام والأديان، ط3، ص57، الدعوة، 2002، القاهرة.

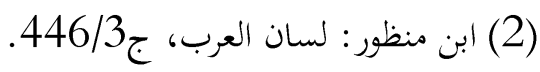

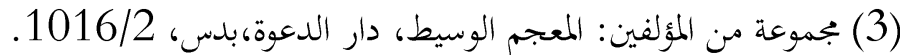

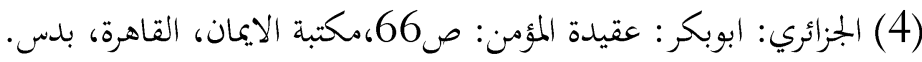

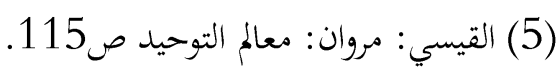

(6) المقريزين: تقي الدين احمد: تجريد التوحيد المفيد: جامعة الإسلامية، صالمالم، المدينة المنورة، 1989.

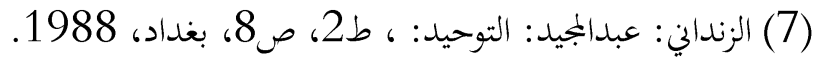

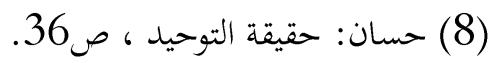

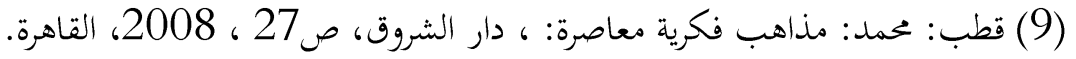

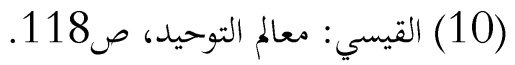

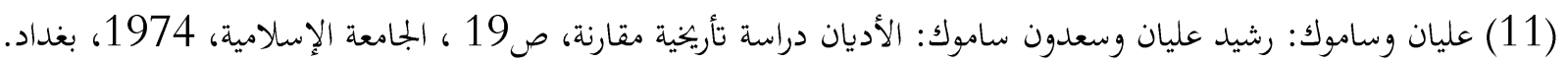

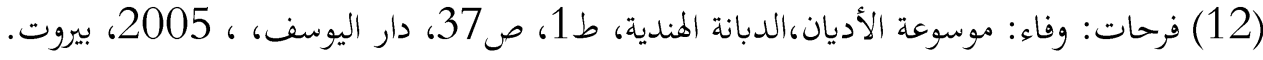

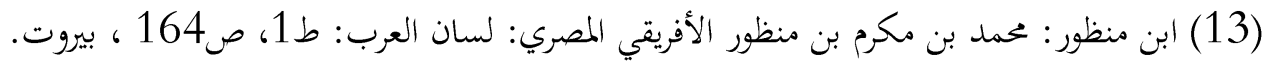

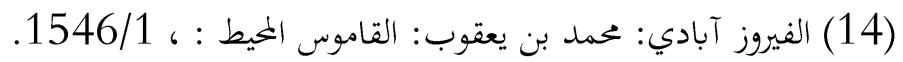

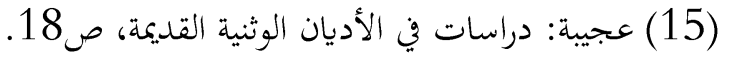

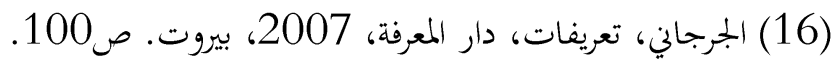

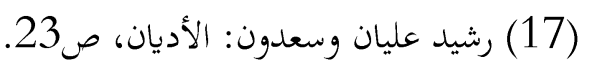

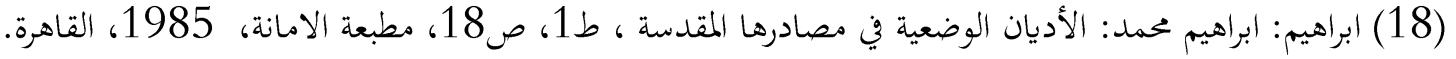

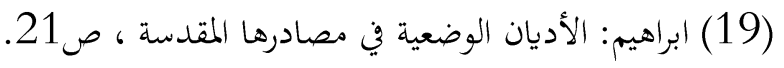

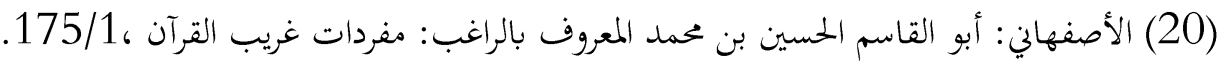

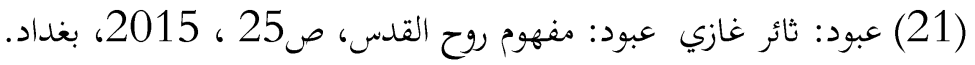

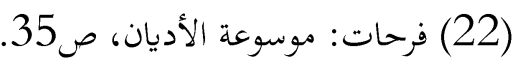

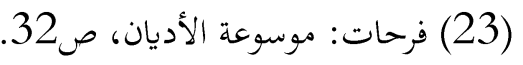

(24) ثالوث: لم ترد كلمة ثالوث في الكتاب المقدس قط، وأول استعمال معروف لها في تأريخ المسيحية كان على لسان ثاوفيلس الانطاكي

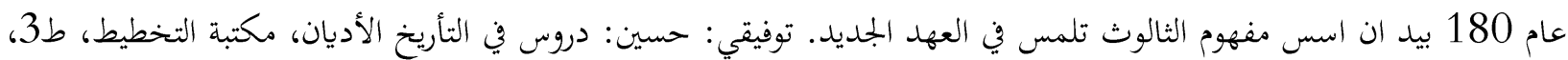

صن: 219، 1388هـ.

(25) نجيب: احمد عبدالكريم: فصل الخطاب، ط2، ص1313 ، 1994 1994، اردن.

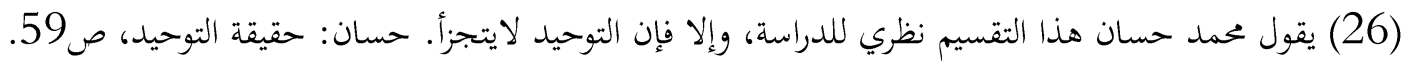


(27) القيسي: مروان إبراهيم: معالم التوحيد، المكتب الإسلامي، 138ص، طانية، 2012، 2012، بيروت.

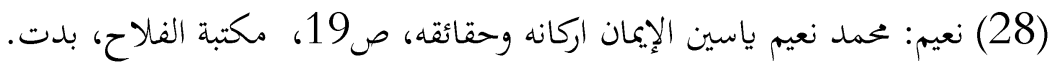

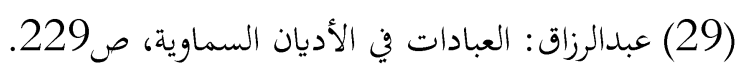

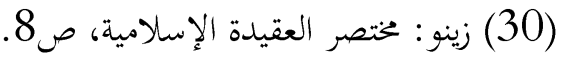

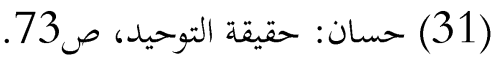

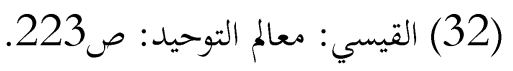$$
\text { (33) حسان: حقيقة التوحيد،صوناص: }
$$

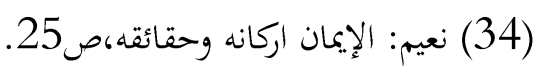

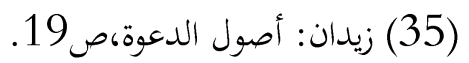

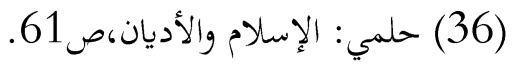

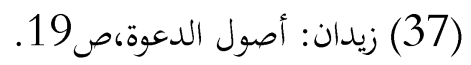

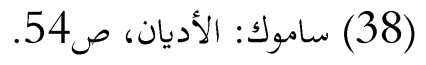

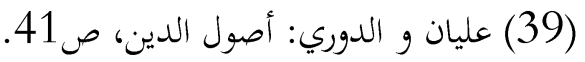

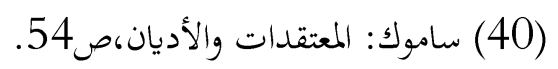

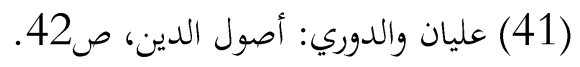

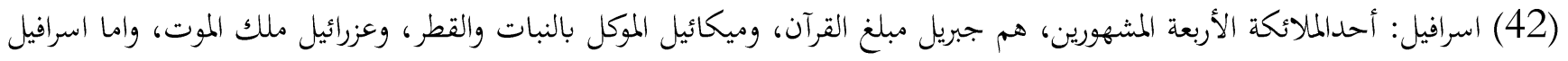

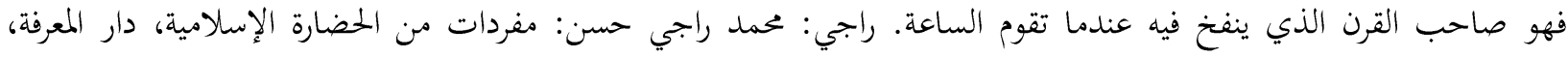

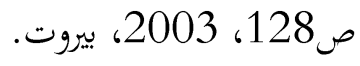

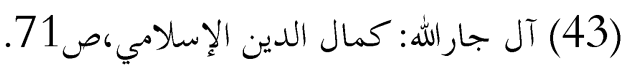

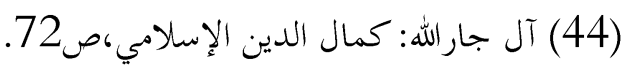
(45) عليان والدوري: أصول الدين، صالن الدان.

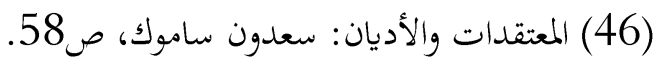

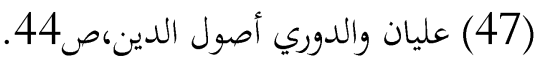

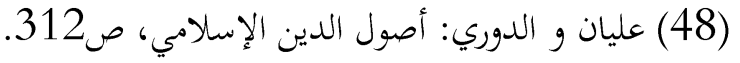

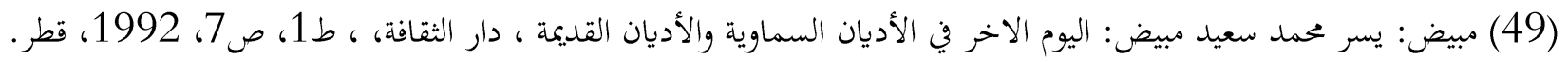

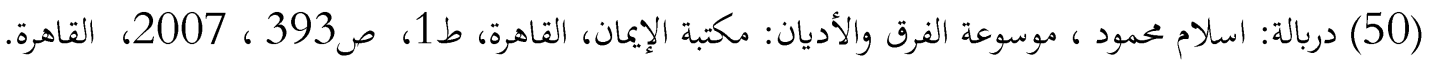

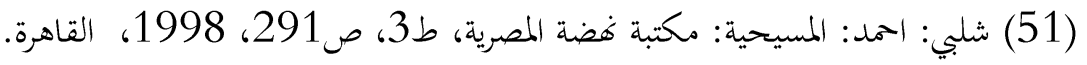

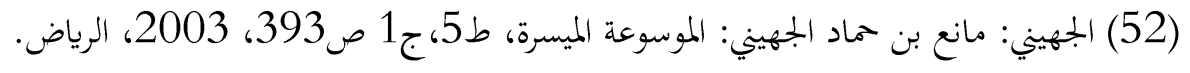

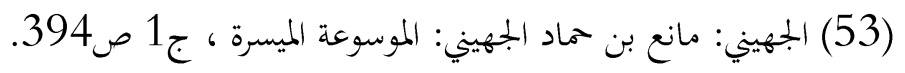




$$
\text { (54) ضياء: دراسات في اليهودية والمسيحية، ص338. }
$$

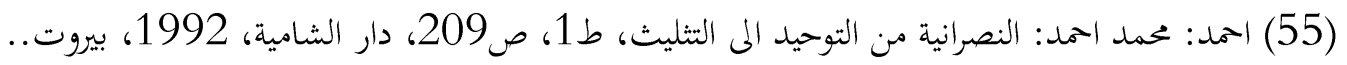

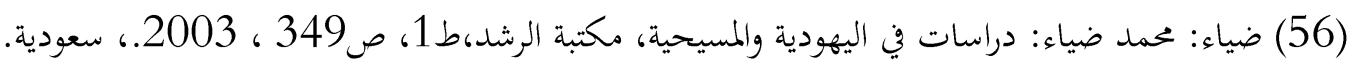

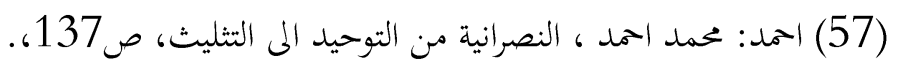

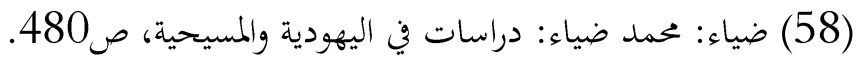

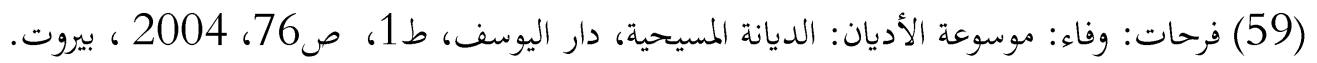

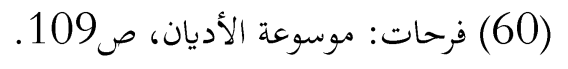

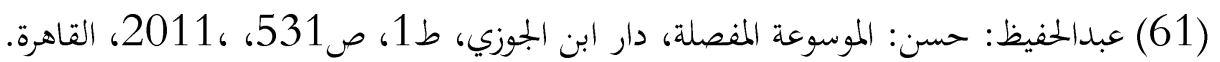

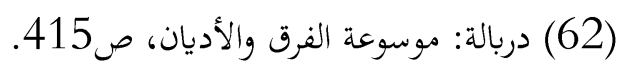

(63) الحفيظ: الموسوعة المفصلة ، 522/2.

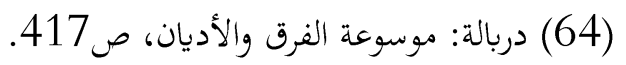

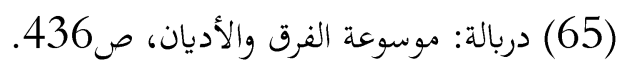

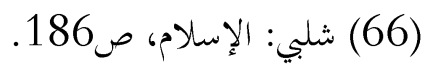

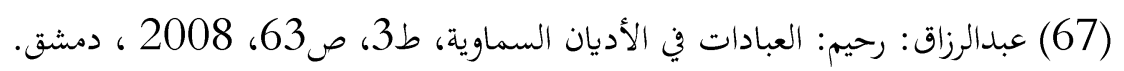

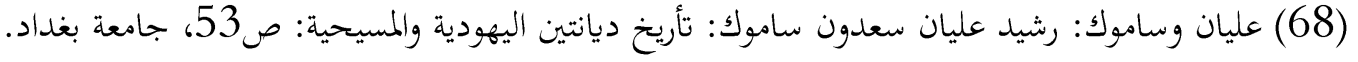

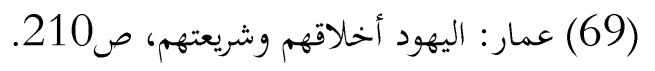

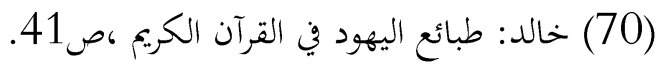

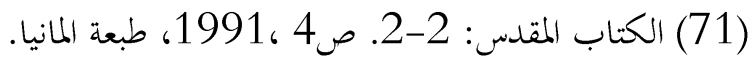

(72) خوار: صوت يشبة صوت البقرة. عويس: موسوعة مصطلحات علوم القرآن، ط1 ، 145/2.

(73) ينظر : عبد الحفيظ الموسوغة المفصلة، ص15.

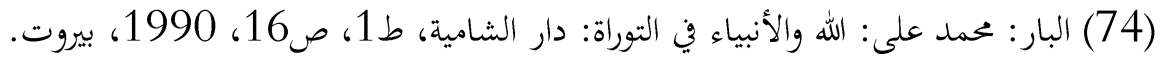

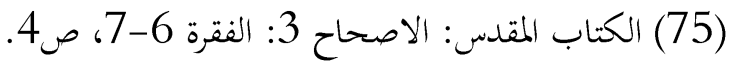

$$
\begin{aligned}
& \text { (76) سفر ارميا: 4:10 } \\
& \text { (77) البار: الله والأنبياء في التوراة، ص27. } \\
& \text { (78) البار: الله والأنبياء، ص30. }
\end{aligned}
$$

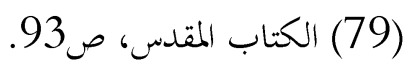

(80) الجوييم: المراد بالجوييم او بالأمميين من عدا اليهود، ومعنى الكلمة عندهم البهائم والانجاس والكفرة والوثنيون، وفي هذا ما يدل ان اليهود

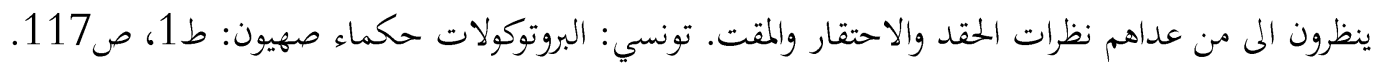

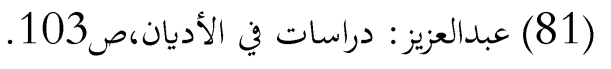




$$
\begin{aligned}
& \text { (82) عجيبة: دراسات في الأديان، ص128. } \\
& \text { (83) شلبي: المسيحية،صو83. }
\end{aligned}
$$

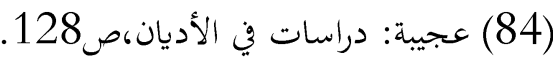

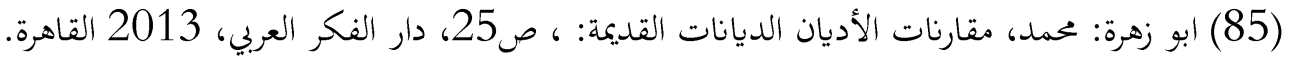

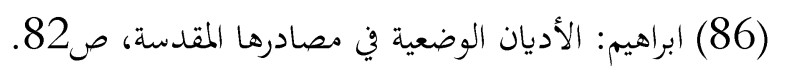

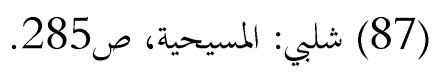

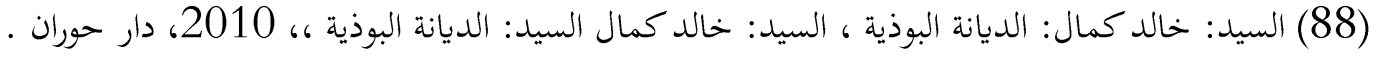

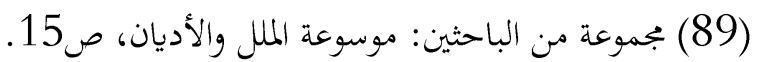

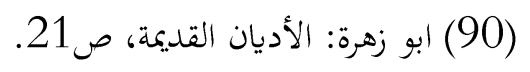

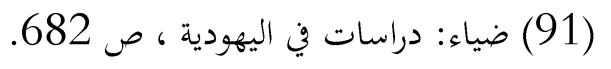

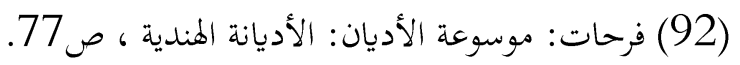

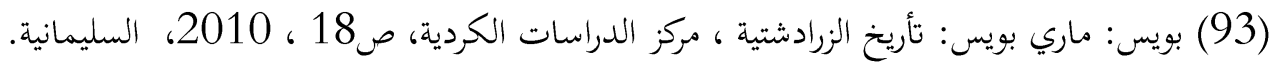

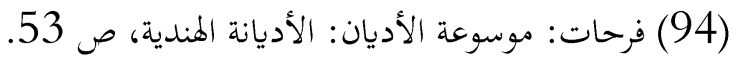

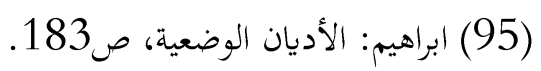

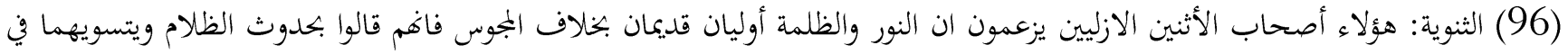

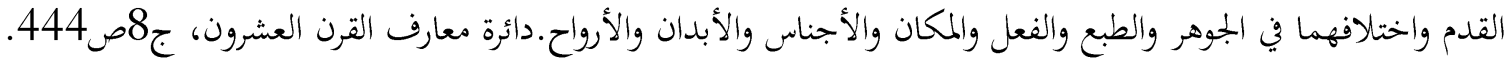

(97) ابراهيم: الأديان الوضعية، ص183.

(98) عليان و ساموك: الأديان، ص131.

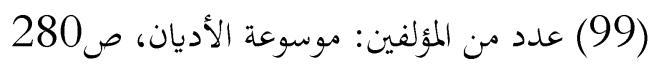

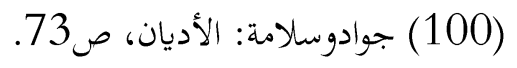

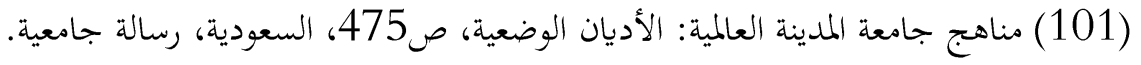

(102) عبدالحفيظ: الموسوعة المفصلة، 743/2.

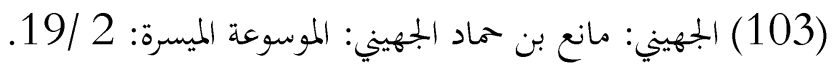

(104) ابراهيم: الأديان الوضعية ، ص2111) المهيني

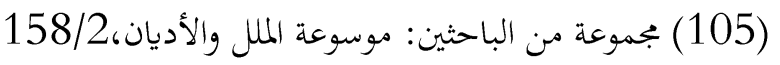

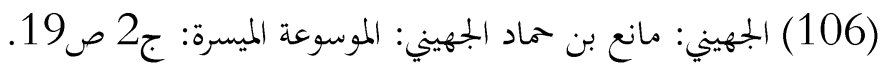

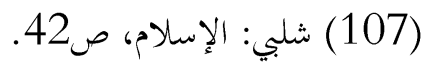

(108) جمموعة من الباحثين: موسوعة الملل والأديان ، 2 / 161)

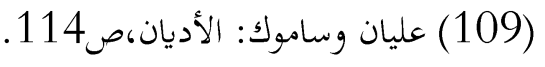




$$
\begin{aligned}
& \text { (110) ساموك: المعتقدات والأديان،ص289. }
\end{aligned}
$$

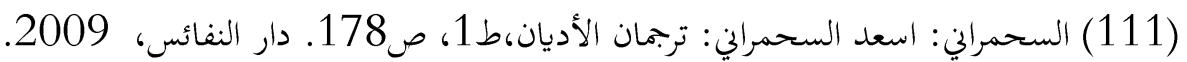

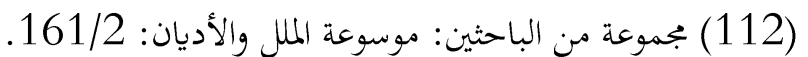

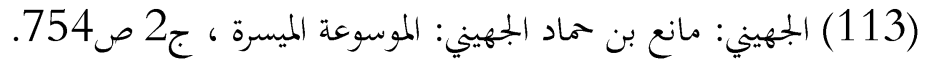

$$
\begin{aligned}
& \text { (114) معتقدات اسيوية: كامل سعفان، ص273. } \\
& \text { (115) سميث: هوستن سميث: أديان العالم ، دار الجسور للثقافة، ط3 ص260، صعان، 2007، 200، حلب. }
\end{aligned}
$$

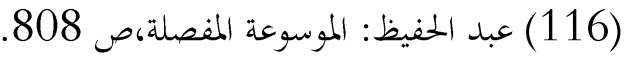

$$
\begin{aligned}
& \text { (117) مجموعة من الباحثين: موسوعة الملل والأديان، 1184) }
\end{aligned}
$$

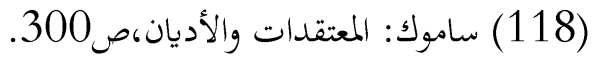

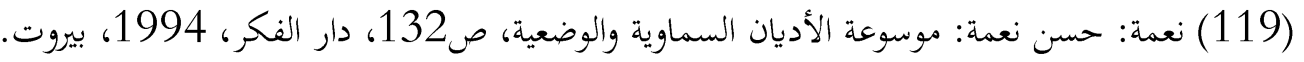

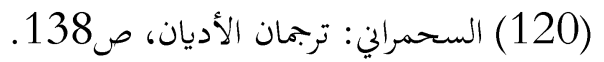

$$
\begin{aligned}
& \text { (121) السحمراني: ترجمان الأديان، ص12154. } \\
& \text { (122) جواد و سلامة: الأديان، ص70. }
\end{aligned}
$$

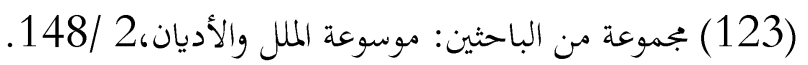

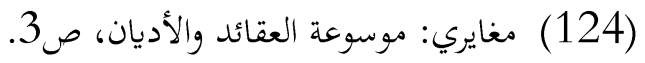

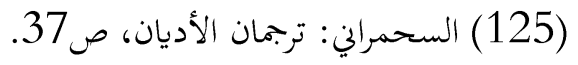

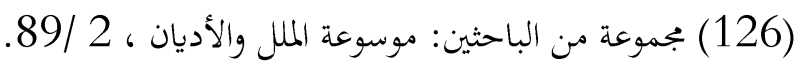

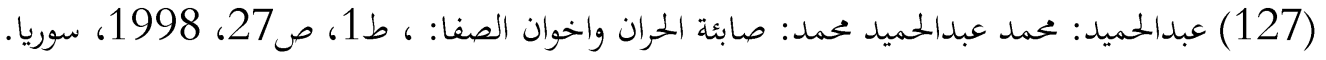

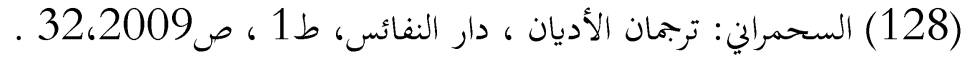

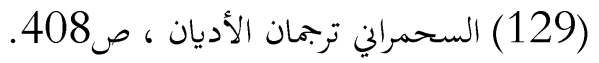

$$
\begin{aligned}
& \text { (130) جواد و سلامة: الأديان ، ص115 (1315. }
\end{aligned}
$$

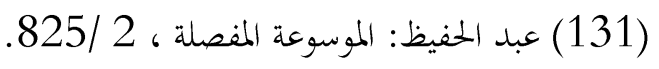

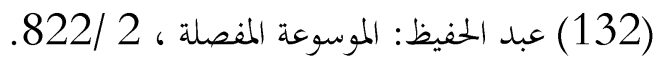

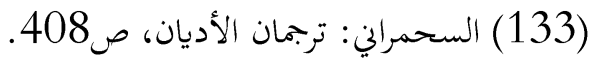

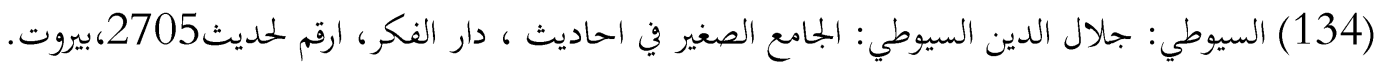

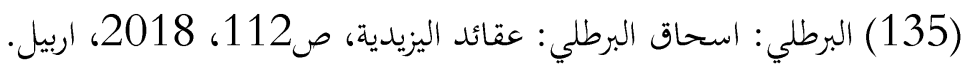

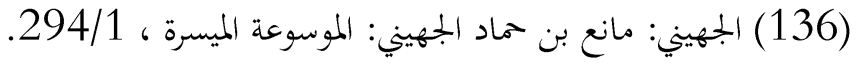

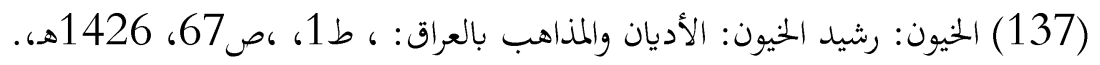

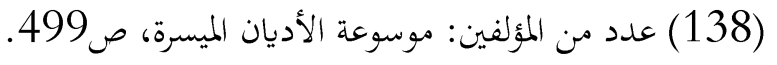


(139) الامين: عبد الله الامين: دراسات في الفرق والمذاهب القديمة والمعاصرة ، دار الحقيقة، ط2، ص273، 1991، بيروت.

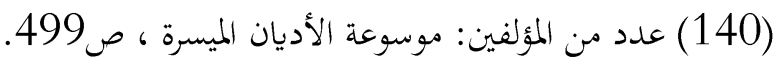

(141) عزرائيل: ملك الموت في تراث اليهود وكثير ما يتحد مع روفائيل في الكتابات اليهودية. معجم ديانات واساطير العالم: 1 /157.

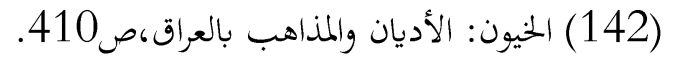

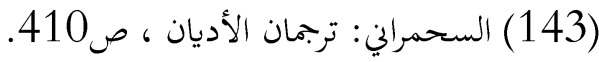

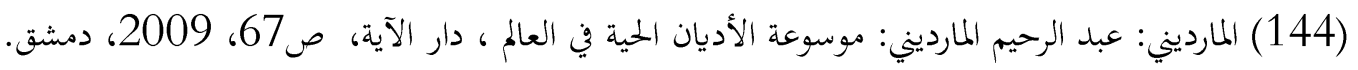

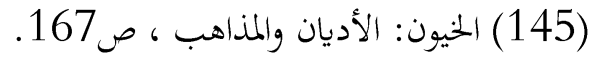

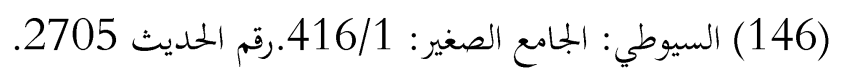

(147) ساموك: المعتقدات والأديان،ص المغير : 313 :

(148) عبدالحفيظ: الموسوعة المفصلة ، 175/1)

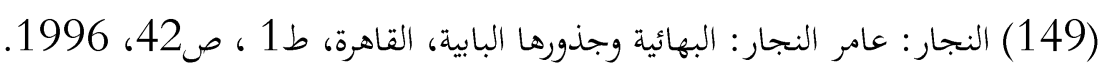

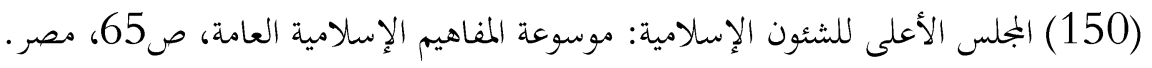

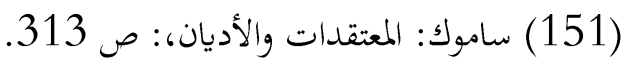

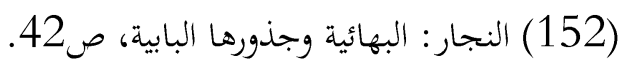

(153) المجلس الاعلى للشئون الإسلامية: موسوعة المفاهيم الإسلامية العامة ، ص65.

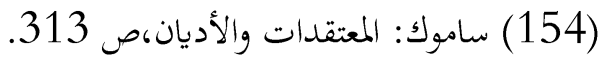

(155) عبدالحفيظ: الموسوعة المفصلة: 175/1.

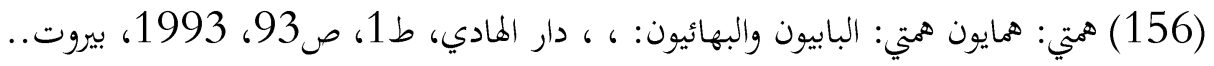

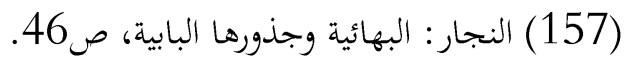

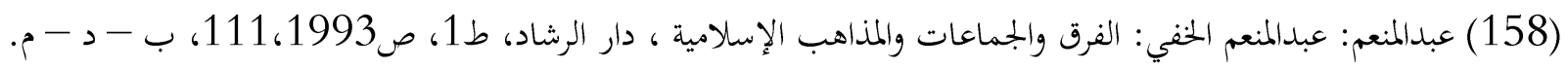

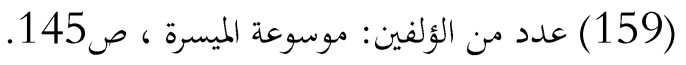

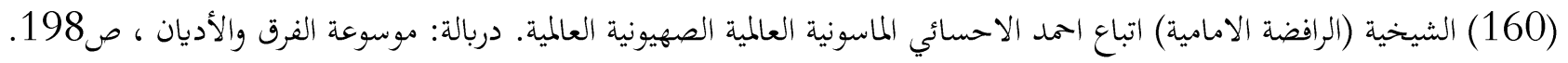

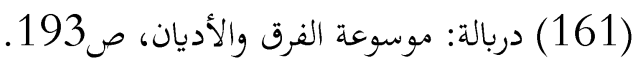

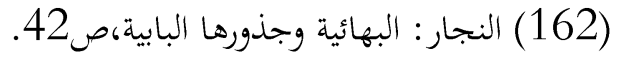

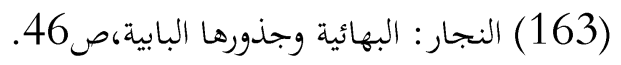

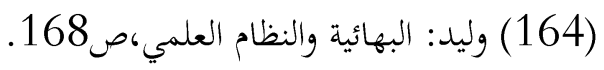

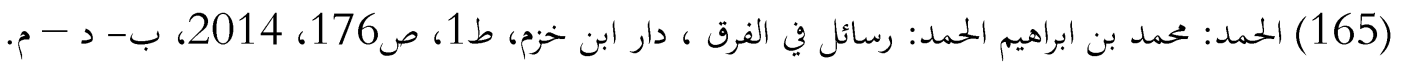

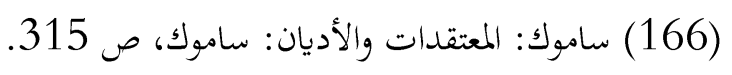

(167) الأسكندري: أبوحفص أحمد بن عبد السلام: فتنة البهائية تاريخهم وعقائدهم وحكم الإسلام فيهم، صاندان صأ22، موقع صيد الخاطر. 


$$
\begin{aligned}
& \text { (168) عدد من المؤلفين: موسوعة الأديان ، ص147. }
\end{aligned}
$$

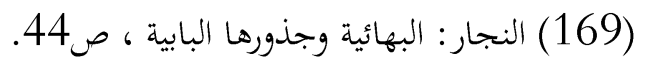

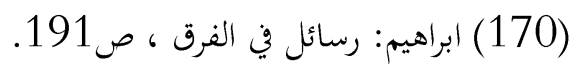

$$
\begin{aligned}
& \text { (171) السكندري: فتنة البهائية تاريخهم وعقائدهم وحكم الإسلام فيهم ، ص30. } \\
& \text { (172) زهران: البهائية ، ص16) }
\end{aligned}
$$

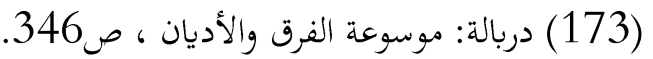

$$
\begin{aligned}
& \text { (174) جمموعة من الباحثين: موسوعة الفرق المنتسبة للإسلامه. ص46. } \\
& \text { (175) عبد الحفيظ: الموسوعة المفصلة: } 2 \text { / } 2 \text { /181. }
\end{aligned}
$$

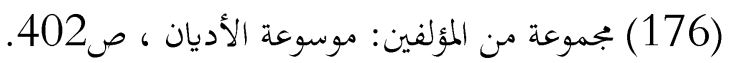

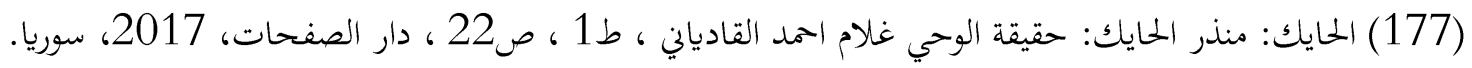

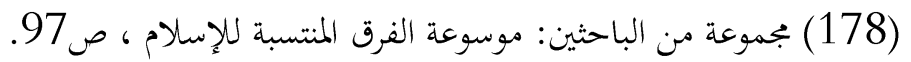

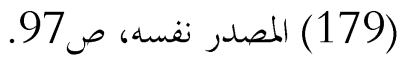

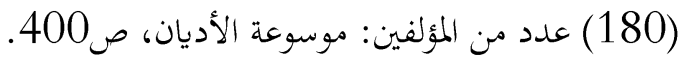

